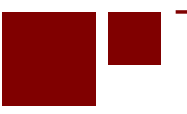

C E N T E R for RETIREMENT

\title{
EXPLORING THE RISE OF MORTGAGE BORROWING AMONG OLDER AMERICANS
}

\author{
J. Michael Collins, Erik Hembre, and Carly Urban
}

CRR WP 2018-3

May 2018

\author{
Center for Retirement Research at Boston College \\ Hovey House \\ 140 Commonwealth Avenue \\ Chestnut Hill, MA 02467
}

Tel: 617-552-1762 Fax: 617-552-0191

http://crr.bc.edu

J. Michael Collins is the faculty director of the Center for Financial Security at the University of Wisconsin-Madison. Erik Hembre is an assistant professor at the University of Illinois at Chicago. Carly Urban is an associate professor at Montana State University. The research reported herein was performed pursuant to a grant from the U.S. Social Security Administration (SSA) funded as part of the Retirement Research Consortium. The opinions and conclusions expressed are solely those of the authors and do not represent the opinions or policy of SSA, any agency of the federal government, the University of Wisconsin-Madison, the University of Illinois at Chicago, Montana State University, or Boston College. Neither the United States Government nor any agency thereof, nor any of their employees, makes any warranty, express or implied, or assumes any legal liability or responsibility for the accuracy, completeness, or usefulness of the contents of this report. Reference herein to any specific commercial product, process or service by trade name, trademark, manufacturer, or otherwise does not necessarily constitute or imply endorsement, recommendation or favoring by the United States Government or any agency thereof.

(C) 2018, J. Michael Collins, Erik Hembre, and Carly Urban. All rights reserved. Short sections of text, not to exceed two paragraphs, may be quoted without explicit permission provided that full credit, including $(\subset)$ notice, is given to the source. 


\section{About the Steven H. Sandell Grant Program}

This paper received funding from the Steven H. Sandell Grant Program for Junior Scholars in Retirement Research. Established in 1999, the Sandell program's purpose is to promote research on retirement issues by scholars in a wide variety of disciplines, including actuarial science, demography, economics, finance, gerontology, political science, psychology, public administration, public policy, sociology, social work, and statistics. The program is funded through a grant from the Social Security Administration (SSA). For more information on the Sandell program, please visit our website at: http://crr.bc.edu/?p=9570, send e-mail to crr@bc.edu, or call (617) 552-1762.

\section{About the Center for Retirement Research}

The Center for Retirement Research at Boston College, part of a consortium that includes parallel centers at the University of Michigan and the National Bureau of Economic Research, was established in 1998 through a grant from the Social Security Administration. The Center's mission is to produce first-class research and forge a strong link between the academic community and decision-makers in the public and private sectors around an issue of critical importance to the nation's future. To achieve this mission, the Center sponsors a wide variety of research projects, transmits new findings to a broad audience, trains new scholars, and broadens access to valuable data sources.

Center for Retirement Research at Boston College

Hovey House

140 Commonwealth Ave

Chestnut Hill, MA 02467

Tel: 617-552-1762 Fax: 617-552-0191

http://crr.bc.edu

Affiliated Institutions:

The Brookings Institution

Syracuse University

Urban Institute 


\begin{abstract}
This paper documents and examines the rise in mortgage usage among older Americans over the past 30 years. It uses data from a variety of sources including the Health and Retirement Study, Decennial Census, American Community Survey, Survey of Consumer Finances, and the American Housing Survey. We begin by documenting the large increase in mortgage usage among older Americans across age and income distributions. We then use regression analysis to test for causes of the mortgage increase and subgroup heterogeneity, in particular focusing on changing health, bequest motives, and tax policy incentives.
\end{abstract}

This paper found that:

- Americans over age 60 are more than three times as likely to have mortgage debt in 2015 compared to 1980, a 24-percentage point increase. This is a consistent increase across the income distribution.

- Increases to homeownership account for some of the rise in mortgages, but this has increased by only 9 percentage points among Americans over age 60 between 1980 and 2015.

- Younger age groups have had much smaller increases, and sometimes decreases, in mortgage usage and homeownership over the same time period.

- Changes in household characteristics, such as education, urbanization, race, income, and marriage rates explain only a small portion of the increase in mortgage rates.

- Households with below-median assets, and those without pensions, account for a greater share of the rise in older households' mortgage borrowing.

- Changes in subjective health and bequest motives explain little of the rise in mortgage rates. Variation in the mortgage interest deduction explains part of the differential increase in mortgage usage by age.

The policy implications of the paper are:

- The beneficiaries of mortgage and homeownership subsidies, such as the mortgage interest deduction, have changed substantially over the past 30 years. 
- Increased mortgage usage has coincided with less total debt among seniors relative to younger cohorts and has not resulted in increased delinquency. This may indicate that the negative aspects of increased mortgage usage are limited.

- Further investigation into the causes and consequences of mortgage usage is needed in considering appropriate policy responses. 


\section{Introduction}

In the United States, the share of all households over age 65 is increasing to the point where one in five household heads will soon be in what are labeled as 'elderly' (Poterba, 2014). At the same time, older households are holding an increasing level of debt (Consumer Financial Protection Bureau, 2014; Vornovytskyy et al., 2011). According to Census data, in 20153.6 million more households aged 65 and older had a mortgage than in 2000, increasing older American mortgage usage by thirty-nine percent. Meanwhile, households under 40 have 4 million fewer mortgages over the same time period.

A traditional life-cycle savings model predicts that individuals borrow at younger ages, then pay off debt and decumulate assets in retirement. Mortgage debt used to buy a home is an example-households borrow at younger ages to buy a home, pay off the loan and then use that asset to consume housing as they age-so called 'imputed rent'. Based on this, older households should be less likely to have a mortgage. However, Figure 1 shows that the rate of older households holding mortgages over time is rising relative to other cohorts. For example, Census data in Panel B of Figure 1 show the rate of holding a mortgage has increased from roughly 10 percent of households near age 70 in 1980 to close to 40 percent by 2015-almost four times the level three and half decades prior. Home mortgage loans are typically the largest loans households take on, and the amortization schedule on these loans means as the loan term expires, the borrower owns the property free and clear of any debt. Yet, recent trends show the rate of older borrowers paying off mortgages is declining. This begs the question, why are seniors increasingly holding mortgage loans as they age?

Some observers suggest that rising levels of debt for older Americans presents a serious problem (Pham, 2011). For example, a report by the Consumer Financial Protection Bureau (2014) claims that "rising mortgage debt is threatening the retirement security of millions of older Americans." Recent work by (Mayer, 2017) highlights increasing debt among retirees relative to financial assets, reporting that in 201240 percent of homeowners aged 65-69 have more mortgage debt than their financial assets, up from 28 percent in 1992. If older homeowners hold mortgages and are burdened with making mortgage payments as they exit the workforce in retirement ${ }^{1}$, they have an added monthly expense, potentially crowding out consumption of other welfare enhancing goods, such as health care, food, and prescription drugs. However, given longer life expectancy and extended labor force participation rates of older workers, and improving health status, households may optimally choose to maintain mortgage debt later in life. Moreover, income tax, es-

\footnotetext{
${ }^{1}$ We acknowledge that retirement from work and elderly status are both defined continuously, with households engaging in variable levels of work even at the older ages. Our assumption is that households 65 and older are more likely to be retired from work, and more likely to receive pension and Social Security income.
} 
tate tax and other incentives may favor holding mortgage debt, combining with life-cycle factors and bequest motives, to make mortgage holding more favorable for more recent elderly cohorts than prior generations.

Older households have three general attributes that make their mortgage choices interesting to study. First, this population has reduced income uncertainty, as they are less likely to have unemployment shocks, and relatively stable income from Social Security and any pension income. They are also more protected from health care expense shocks given Medicare coverage.

Second, elderly households are less location constrained, since they are less likely to be commuting to work, and are unlikely to have school-age children. Given lower opportunity costs of time, these households also have lower transaction costs of moving. ${ }^{2}$ Combined with greater locational flexibility, these factors could encourage households to sell their homes and then rent or downsize to a lower cost property that does not require financing. Selling a home frees up home equity than can be used for investment or consumption.

Third, the boom-and-bust housing cycle of the 2000s had a dramatic impact on home values and access to mortgage debt. As shown by Bhutta and Keys (2016), unprecedented real housing gains in the boom period, combined with low interest rates, led to high rates of equity extraction among homeowners. As home values plateaued and then declined, homeowners in many parts of the country faced large losses and even home foreclosure. The house price decline was most problematic among borrowers with lower downpayments, early in their loan repayment schedule, who had a negative income shock. Older households may have been less likely to have had an unemployment shock in the recession, and more muted income declines relative to younger households. This likely protected them from defaults, but still exposed their household balance sheets to the full brunt of the housing bust as home values declined. Lower home values may have also delayed older household's plans to sell their homes or downsize, leaving households to maintain their current home and mortgage. Older households may have also been indirectly impacted by the recession through their adult-aged children who needed in-kind or cash inter vivo transfers, which could delay paying off a mortgage. The net effect of this volatile period on the mortgage decisions of older households remains ambiguous.

This study provides a deeper understanding of the prevalence of mortgages among older households. First, we ask how the underlying trend in elderly mortgage rates has evolved over time, using four complementary datasets: the Health and Retirement Study (HRS), the Survey of Consumer Finances (SCF), the American Community Survey (ACS) and related Census data, and the American Housing Survey (AHS). Second, we investigate

\footnotetext{
${ }^{2}$ Homeownership can limit mobility; Dietz and Haurin (2003) describe that home sales entail substantial transaction costs.
} 
the extent to which some subgroups within the elderly population have greater growth in the rate of mortgage borrowing. Third, we explore policy and economic changes in recent decades that could contribute these shifts towards elderly mortgage borrowing.

This study complements recent work by Mayer (2017) and Lusardi et al. (2017a) which both consider housing finance choices among older Americans. Mayer (2017) documents evolving trends in homeownership and mortgage finance among older adults over the past several decades. He reports that while homeownership rates among older adults has been increasing over time, that mortgage usage has also been increasing without a corresponding increase in financial assets as well suggesting the financial stability among retirees is getting worse. Lusardi et al. (2017a) uses data from the Health and Retirement Study from 1992, 2004, and 2010 to show that recent cohorts entering into retirement have taken on more debt than in the past, largely to purchase higher priced homes with smaller down payments. We also observe this trend, but we show an increase in mortgage debt for post-retirement households. We further build upon Mayer (2017) and Lusardi et al. (2017a) by examining the heterogeneity in these trends and potential rational explanations for the increased debt load.

Increasing mortgage borrowing could have significant implications for the financial wellbeing of retired households. Given historically low mortgage interest rates, households may simply be exploiting financial arbitrage between investment and borrowing rates. Households could be able to increase long-run consumption and reach a higher level of welfare. In recent work, Goodman and Mayer (2018) provide evidence that even over the boom-bust housing cycle owning a home was generally financially advantageous relative to renting. However, borrowing could be a risky strategy, especially if households cannot maintain payments and default on their loans. If households are borrowing mainly to tap home equity for consumption, and lack the ability to service debt payments, then rising debt levels may suggest potentially worsening outcomes for households.

Using four datasets, we explore the phenomenon of debt holding by older households. We document that older households are more likely to hold a mortgage, and have larger mortgages, than in previous decades. This rise in mortgage borrowing has been steady over time and consistent across income groups and geographic regions. Perhaps unsurprisingly, the largest explanatory factor for increased mortgage borrowing is increased homeownership among older Americans. Yet even conditional on homeownership, mortgage borrowing has risen considerably. Other factors contributing to increased mortgage borrowing include tax subsidies, rent-to-price ratios, and increased housing consumption. Many other observable factors such as changes to income, education, bequest motives, or kids do not appear to be driving increased mortgage borrowing. There are no signs these borrowers are defaulting at higher rates, and these households appear to have more assets as their debt levels rise. Instead it appears in recent years older homeowners have been holding on 
to their homes, extending the terms of their mortgages to potentially smooth consumption and access more liquid savings, or refinancing to access equity. Whether these patterns are sustained as housing prices continue to increase, income tax laws change, and interest rates increase, will be important to monitor over the next decade.

\section{Background}

Younger households with higher expected future income and little current savings can use debt to smooth consumption over the life course. As households' ages and incomes peak, these households can pay down and eliminate this debt while saving for retirement. The prediction from standard models is that older households will hold relatively less debt than younger households. As households age, they can take on one of three housing situations: (1) Own a home outright, without a mortgage; (2) own a home with mortgage; and (3) rent a home, either for cash, or a no-cash rent, such as living with relatives. An increasing number of older households are choosing option (2) and this paper seeks to understand why.

Mortgage debt is used to finance a property, typically an owner-occupied residence that offers a stream of housing consumption to the owner. The standard U.S. mortgage loan has a 30-year repayment term. This means that a mortgage originated when a household is 30 would naturally terminate by age 60 , assuming no refinancing, prepayments, or selling

of the home. Households who take out a mortgage at older ages could still pay off the loan ahead of schedule, use savings to pay off the balance, or sell the home to pay off the loan.

Older homeowners who lack assets to pay off their mortgage can sell their homes, and then use the proceeds to fund consumption or investments while renting a home. Renting may also be a way for aging households to avoid directly paying increasing property taxes (Shan, 2010). Older homeowners can also downsize their living space by selling their home and renting a smaller housing unit. Rental properties typically require less physical maintenance, which could be attractive to older households with physical limitations (Golant, 2008a b).

Despite these potential benefits, the general trend is not for older households to transition from homeownership to renting. Painter and Lee (2009) study the housing tenure decisions of older households using the Panel Survey of Income Dynamics and conclude that age does not directly relate to households transitioning from ownership to renting. Shocks such as having a lower health status or becoming a single head of the household are more predictive than age alone. While there have been changes in the delivery of health care that may facilitate older households staying in their homes in spite of health shocks, there is also not strong evidence health care policies are contributing to more homeowner- 
ship among the elderly (Engelhardt and Greenhalgh-Stanley, 2010).

Older households may prefer homeownership since it could provide more predictable housing costs than rental markets subject to annual contracts (Sabia, 2008; Sinai and Souleles, 2005). Aging households may also prefer owner occupied homes to be able to control the level of investment they make in home maintenance. Aging homeowners can smooth consumption by forgoing home maintenance, essentially reducing the equity value of the home over time and consuming what would have otherwise been spent on home repairs (Gyourko and Tracy, 2006). Another factor that may contribute to homeownership of older households is the steady rise in Social Security benefits, which reduce income uncertainty in retirement (Engelhardt, 2008). Overall, the evidence suggests that older households tend to remain in owner occupied homes as they age (Golant, 2008a b). This leaves the question: why are older households more likely to use a mortgage than before relative to other age cohorts?

There are several reasons why home-owning households may strategically maintain mortgage debt as they age. First, financial planners counsel households on the tradeoffs of paying off a mortgage as part of retirement planning (Nason, 2017). Since mortgage interest rates are often a low cost form of borrowing, households can leverage their portfolios by arbitraging the difference between the costs of borrowing and real rates of return when investing in markets. Such strategies can be risky, since the home is collateral for the loan and the asset values of investments and housing can decline. It is unclear that the average older household would have the ability to effectively borrow to invest, especially given low levels of measured financial literacy (Lusardi et al., 2017b).

A second reason older households may maintain mortgage debt as they age is because of tax incentives. At the federal level, and in most states, mortgage interest is deductible from income taxes. Several studies, including Hanson (2012) and Hilber and Turner (2014), examine the influence of the mortgage interest deduction on housing decisions. There is little evidence that the mortgage interest deduction has an impact on the extensive margin of the homeownership rate, although Hanson (2012) finds an intensive margin effect of the mortgage interest deduction on home size. While there are other tax incentives related to housing, such as the ability to deduct property taxes from income, the exclusion of capital gains from income taxes, and imputed rent from taxation, these all encourage homeownership, though not specifically borrowing or extending a mortgage.

The tax incentives of mortgages should prioritize mortgage debt over shorter-term consumer debt, such as automobile loans and credit cards, which typically charge higher rates. The tax incentives lower the effective, after-tax interest rates of mortgages, making it less costly to finance current consumption through mortgage debt than to draw down financial investments. Amromin et al. (2007) show that the tax-exemption of certain retirement savings accounts means households might be better off if they continued to borrow 
using a mortgage loan while putting money into retirement accounts. The authors do not find evidence of this behavior, however. Part of the issue is that the mortgage interest tax deduction requires itemizing, which typically only applies to higher-income borrowers (Poterba and Sinai, 2008a).

A third reason households may hold mortgages as they age is the need to borrow to fund consumption. Poterba et al. (2011) show a pattern that is consistent across many studies: many households have little savings even as they close in on retirement. Home equity is one of the primary stores of non-pension wealth, especially for low-income and less wealthy families (Bricker et al., 2012). Home equity may be one of the few ways households with little other savings can smooth spending or respond to financial shocks. Among all households age 65 to 70 in 2008, real estate represented 48 percent of nonSocial Security or pensions wealth (Poterba et al., 2011). Several studies show households often use home equity as a source of liquidity. For instance, Bhutta and Keys (2016) use a panel of consumer credit reports to document high rates of home equity extraction as a result of increasing house prices and low interest rates in the early 2000s. They further show that households use this equity to pay down other consumer debts. Davidoff (2010) show home equity may substitute for long-term care insurance, and therefore a useful financial planning strategy. However, the value of home equity can be volatile, which presents a substantial risk for homeowners. Lusardi and Mitchell (2007) even suggest that some households in retirement have less home equity due to failure to plan ahead to pay off their mortgages.

Moulton et al. (2017) study home equity conversion mortgages, or reverse mortgages, which is a type of loan designed for liquidity constrained borrowers age 62 or older where the balance is not due until the home is sold or the borrower is deceased. They compare otherwise similar reverse mortgage borrowers to borrowers of traditional (forward) home equity mortgages, finding reverse mortgage borrowers are more likely to pay down existing debt. While reverse mortgages are subsidized by the U.S. Housing and Urban Development Home Equity Conversion Mortgage default insurance program, only a small fraction of senior homeowners utilize the product (Moulton et al., 2017; Shan, 2011). In part this is due to the lowest income households not having sufficient home equity to produce significant financial benefits (Venti and Wise, 1991).

This summary of the literature suggests that homeownership among the elderly is likely to be persistent across successive cohorts of the same age, but offers few insights into why more recent cohorts of older homeowners are borrowing mortgages at higher rates than in the past. This study examines household and market level factors that could influence mortgage holding by older homeowners over time compared to other age cohorts. 


\section{Data}

The analysis in this paper draws on four datasets to describe trends in mortgage holding across age cohorts. While we mainly use the HRS, we supplement our findings with three additional datasets. Below, we briefly describe each of these widely-studied datasets.

\subsection{Health and Retirement Study}

The HRS is a biennial panel survey designed to track the demographic characteristics, health status, and financial assets of households 50 years and older in the United States. Beginning in 1992 with an initial cohort of 12,652 respondents, the HRS's primary respondents were born between 1931 and 1941. To cover the full age distribution above 50 years, the HRS has added additional cohorts over time and as of 2014 has a sample of 18,747 people. Of particular interest for this study, the HRS collects information on housing tenure status, mortgage status and payment amount and other measures. We utilize restricted-access HRS data, which includes geographic location information at the census tract level, allowing us to include housing market variables such as house price levels, rent-to-house price ratios, and unemployment rates. In our analysis, we restrict our sample to primary respondents between the ages of 50 and 100, leaving a sample of 119,151 household-year observations between 1994 and 2014.3

\subsection{Census}

We use data from the 1980, 1990, and 2000 PUMS decennial Census, and 2005, 2010, and 2015 American Community Survey to document the rate of older households owning homes and having a mortgage. We use a random sample of about a half-million households from each wave of these Census data, again excluding households younger than 50 , and older than 100. There are a total of six waves, covering a 35 year period. This dataset gives us the longest time horizon with which to study mortgage rates. Throughout, we refer to this as the Census data for simplicity.

Each observation in the data is a household, reporting on the prior year. The Census data include housing tenure (rent, own with a mortgage, or own without a mortgage). We observe the age of household head, household income, household size, martial status, and state of residence. In addition, it includes state identifiers. However, the Census data do not include information regarding household assets.

\footnotetext{
${ }^{3}$ There are 238 households subject to attrition from the panel; there are no statistical differences in attrition by ownership or mortgage status.
} 


\subsection{Survey of Consumer Finances}

The SCF data provide a comprehensive look at households' personal finances. The study is repeated cross-sectional data administered by the Federal Reserve Board in conjunction with the Department of the Treasury with triennial surveys since 1983. The greatest advantage of the SCF relative to the HRS and Census data is the detailed collection of household financial attributes including total assets and net worth, mortgage usage, home equity, pensions, savings, and delinquent debt payments. While the SCF contains questions not included in the HRS or Census, it does not provide geographic identifiers to protect confidentiality of respondents. Since the earliest SCF surveys to not contain our variables of interest, we begin our analysis with the 1989 survey.

\subsection{American Housing Survey}

The AHS is conducted by the Census Bureau for the Department of Housing and Urban Development. Collected biannually since 1973, the AHS is the most comprehensive national panel survey on housing, containing a battery of questions related to the characteristics of housing units and occupants, including homeownership, home improvements, mortgages, and housing costs. However, the dataset does not have a large sample of housing units occupied by older Americans, and it does not contain the detailed financial measures of other datasets. We only use these data to plot trends over time.

\subsection{Trends in Mortgages, Homeownership, Wealth and Retirement}

We begin by documenting the rate and level of mortgage debt over the past thirty years. Figure 1 clearly illustrates this trend in mortgage rates using data from the AHS (Panel A) and Census (Panel B). Overall, individuals are less likely to have a mortgage as they age, and the patterns in 2009 are quite similar to 1999 and 1989 for households under 55. However, homeowners older than 55 in 2009 are much more likely to have a mortgage than in previous decades. Indeed, the dashed black line representing 2009 breaks away from the solid black and grey lines representing 1989 and 1999, respectively, as age increases.

Increased mortgage borrowing is partly due to increasing homeownership rates among older Americans. Figure 2 reports homeownership rates by age using data from the Census. Between 1980 and 2015, homeownership rates actually decreased for those under 50, likely due to marriage and career trends for this group $4^{4}$ While homeownership rates steadily increase as households age, they peak around 80 percent when households are in their 60s. The interesting pattern occurs after the intersection of homeownership rates

\footnotetext{
4 Gruber et al. (2017) point out a comparable trend in Denmark.
} 
in 2015 (and to a lesser extent, 2000) with rates of previous years near age 65. Younger households in 2015 are less likely to be homeowners than in previous years, and older households are more likely. In fact, the largest absolute change in homeownership rates between 1980 and 2015 is for the 80-84 age group, which has increased homeownership rates by 18 percentage points.

Figure 3 uses the HRS waves from 1998 to 2014 by age to illustrate trends in wealth (in constant 2014 dollars) and retirement rates. The general pattern in Panel A is wealth accumulates as households approach retirement ages, then plateaus or declines. Wealth is lower in 2010-2014 than 2004-2008, reflecting the economic cycle. Only the older 19982002 data show a decline in wealth with age. That trend is similar using the proportion of households by age with wealth of at least $\$ 50,000$ (Panel B)-decreasing at older ages for the earlier cohorts and flatter at older ages for more recent cohorts. Figure 3 Panel C displays the share of households who are report being retired from work. Here the patterns are very similar across age cohorts where most households transition to retirement between ages 60 and 70 . Changes in work or retirement do not seem to have changed in recent age cohorts the way that wealth holding has.

\section{Empirical Strategy}

To determine the change in mortgage prevalence across cohorts and over time, we estimate Equation 1 using the HRS, SCF, and Census data for each time period. Each sample allows for different measures, including different degrees of information regarding the geographic location of the respondent. We focus on household heads in two groups, age 65 to 79, and then age 80 to 100 , compared to those slightly younger, aged 50 to 64 . When comparing the 65 to 79 cohort to the 50-64 cohort, we will plot the estimated difference by year. (The estimated difference between the 80-100 year olds and the 50-64 year olds are shown in the appendix.) We estimate $\alpha_{1}$ in Equation 1 to begin to understand the decrease in the mortgage rate gap between older and slightly less older households in recent decades.

$$
Y_{i}=\alpha_{0}+\alpha_{1} A 2_{i}+\alpha_{2} A 3_{i}+\boldsymbol{\beta}_{1} \boldsymbol{X} \mathbf{1}_{i}+\boldsymbol{\delta}_{s}+\varepsilon_{i}
$$

In Equation 1, $Y_{i}$ is a binary variable equal to one if individual household $i$ currently has a mortgage and zero otherwise. (We choose a linear probability model for ease of interpretation, but our results are comparable if we instead use a logit.) $X \mathbf{1}_{i}$ includes number of children, logged total income, an urban area indicator, education level, race indicators, and a marital status indicator.

A 2 and A3 are the second and third age cohorts comprising those ages 65-79 and 80-100, respectively. The excluded age group are ages 50-64. When we use HRS and 
Census data, we include $\delta_{s}$, state fixed effects. However, with the SCF data, we do not have access to information on the respondents' locations. We include household weights in all regressions, though the results remain consistent if we do not weight the regressions.

The coefficients represent the 'gap' between the prevalence of mortgages for 65-79 year olds and 50-64 year olds - if the estimates by year are less negative, then older households are closing the gap and becoming more likely relative to younger households to have a mortgage.

\section{Findings}

We start by estimating a baseline rate of mortgage borrowing using the specification in Equation 1. Figure 4 displays the coefficients and 95\% confidence intervals of the gap between mortgage holding of households age 50-64 versus those age 65-79, for each survey year in the HRS, SCF, and Census. All models use the controls for demographic characteristics to estimate the rate of households having mortgages by year. The 'gap' is almost always negative, but the slope of the line is increasing, meaning this gap is narrowing over time as older households catch up to younger households in terms of having a mortgage. The mortgage gap between older and middle-aged generations has decreased over time.

\subsection{Exploring Heterogeneity by Age Profiles}

We next seek to explore heterogeneity in these changing trends. Figure 5 reports the estimated $\alpha_{1}$ coefficients from Equation 1 , along with the estimated standard errors bars around each coefficient for 65-79 year olds relative to 50-64 year olds.

Panel A in Figure 5 shows that the gap between the two age groups is smaller for those with children in the household since 2010. The trend mimics the overall trend; in most periods there is no difference in the mortgage rate between the two groups by age, controlling for other factors. The 2013 data are the exception, following the recession, the rate mortgages among of those with children in the household rises to the same levels as the younger cohort-effectively erasing the gap. This could be due to older households taking on more debt, or slowing down debt payments, in order to support their family members.

Panel B of Figure 5 shows those households where the head or spouse have a defined pension compared to those without pensions. Prior studies suggest rising levels of annuitized income may encourage owning a home, and perhaps therefore more borrowing (Engelhardt, 2008). There is selection in play, however, since people with pensions likely had careers and access to benefits that are different in multiple dimensions from those 
without pensions. In most periods, the gap is smaller for those without pensions, as they are more likely to have mortgages. The trend over time is generally for a shrinking gap for both groups, however. Since fewer younger Americans today even have an option to work for a company with a pension, this trend may signal that future generations will hold mortgages longer.

Panel $\mathrm{C}$ of Figure 5 suggests that the decreased gap between the two age cohorts is more pronounced for those with more than a high school education initially but closes with time, suggesting that this population is becoming increasingly likely to hold mortgages over time. This could in part be due to increases in educational attainment over time. The gap in mortgage rates across the two age cohorts is less pronounced for those with high school degrees or those who did not complete high school. The trend for both groups shows a closing of the gap, with more mortgage holding at older ages.

Panel D of Figure 5 splits the sample by those above and below median net worth (roughly $\$ 500,000$ in 2016 dollars). Those below median net worth are largely closing the gap between the two age cohorts: those 65-79 year olds with below median levels of net worth are equally likely to have a mortgage as those 50-64 year olds with comparable net worth by 2016. At the same time, those $65-79$ year olds above median net worth remain 25 percentage points less likely to hold a mortgage than 50-64 year olds with above median net worth. This story is consistent with a potential need for consumption for those with lower levels of assets; wealth and mortgage borrowing behave like substitutes.

The bottom row of graphs of Figure 5 (Panels E and F) use the HRS to examine patterns from 1998 to 2012, again with the gap in mortgage rates for those 65-79 years old compared to 50-64 year olds, controlling for other variables. These estimates are also shown in Table 1 Panel E splits the sample state unemployment rates. The pattern here shows a narrowing gap for those households located in states with higher unemployment, consistent with borrowing to smooth consumption, or support family members to smooth consumption. Panel F uses an HRS question item about bequest intentions-here we might expect those households who plan to donate their wealth to their heirs would prefer to pass on a home free and clear of a mortgage. It is in fact the households without a bequest motive are less likely to borrow at older ages relative to those at younger ages, and the pattern of those with bequest motives shows no gap with the mortgage rates of younger households. We suspect this is mainly due to people who are more altruistic in their bequest intentions also using mortgages during their lifetime to smooth consumption and support inter vivos transfers.

One explanation for rising mortgage rates could simply be older households are more likely to own a home than before. Figure 6 shows the difference in homeownership rates for 65-79 year old households relative to the 50-64 age cohorts. Indeed, relative ownership rates are rising for older households. But the rate of households having mortgages condi- 
tional on homeownership is also increasing. The gap in mortgage rates really appears from 2005 to 2015. Thus, the increase in homeownership alone cannot explain the decreasing gap in mortgage rates across age cohorts.

Figure 7 explores two potential other mechanisms: home values (in constant dollars) and the use of mortgages on second homes. Panel A shows the gap between home values of the 65-79 year old cohort relative to younger cohorts has increased since 2000 by a large margin-over $\$ 20,000$ or about $10 \%$ of average home values. Increased housing consumption may indicate a growing preference among older households towards housing. This contributes to greater mortgage borrowing as households may not have enough financial assets to own their optimal home size outright. Panel B shows mortgages on second homes. Here again, the gap is narrowing over time, with older households more likely to take on mortgages on second homes over time. These estimates are small in magnitude, however.

Building on the patterns in home values, Figure 8 shows estimates of the relative difference in the rates of extracting home equity and refinancing by age cohorts using the SCF. The relative rates of both refinancing and cashing out equity has narrowedconsistent with the home values in Figure 7 -being used for borrowing. This is echoed in Panel B, where the gap between the cohorts in home equity is decreasing since 2007, as more equity is being extracted among older households when compared to their younger cohorts-again compared to Figure 7 this is striking. This suggests an important mechanism: older households are extending the terms of their loans to potentially smooth consumption and access more liquid savings to finance investment activities or consumption as they age at higher rates than before.

Next, we investigate the availability of liquid savings amounts over time in Figure 9. Panel A. Liquid savings is defined in the SCF as funds in checking, savings, money market, and call accounts. Households face a tradeoff between increasing mortgage borrowing to gain liquid savings or reducing mortgage borrowing using liquid savings. The gap between 65-79 and 50-64 year olds in liquid savings varies by year, with perhaps a modest downward trend, but the confidence intervals are large. Older households have higher levels of liquid savings relative to the prior age cohort.

Higher mortgage debt is a problem if households canot service the debt payments. The pattern of loan defaults — defined as being 60 days late - relative to other age cohorts could signal that as older households take on more debt they also are more likely to default. Panel B shows older households are less likely to be at least 60 days late on any account than younger cohorts in most periods. While the difference between the two age groups has decreased from 2010 to 2016, overall, the difference in delinquency rates across the two age groups in 1989 and 2016 are not statistically different from one another at the $95 \%$ level. This is consistent with findings in Brown et al. (2016), showing older borrowers (age 
50-80) have the highest credit scores and lowest delinquency rates.

\subsection{Tax Policies and Rental Markets}

Next, we examine variation in the economic and policy environment over our period of interest to understand the magnitude to which they impact the gap between older and younger cohorts' mortgaged rates . We explore subsidies from the Mortgage Interest Deduction (MID) and rent to price ratios (RTP) in Equation 2.

$Y_{i s t}=\alpha_{0}+\alpha_{1} A 2_{i t}+\alpha_{2} A 3_{i t}+\alpha_{5} P_{i s t}+\alpha_{6} A 2_{i t} \times P_{i s t}+\alpha_{7} A 3_{i t} \times P_{i s t}+\boldsymbol{\beta} \boldsymbol{X}_{i t}+\delta_{s}+\gamma_{t}+\varepsilon_{i s t}$

In Equation 2, we control for the same characteristics $\left(\boldsymbol{\beta} \boldsymbol{X}_{i t}\right)$ from Equation 1, as well as state $\left(\delta_{s}\right)$ and time fixed effects $\left(\gamma_{t}\right) . P_{i s t}$ are state level unemployment rates, state level MID subsidies or and MSA-level RTPs. We cluster standard errors at the state level throughout. The excluded age group is 50-64 year olds.

In Table 1, we report the effect of the state-level unemployment rate by age on the prevalence of having a mortgage. Here, a one unit increase in the unemployment rate increases the gap between 65-79 and 50-64 year olds by 0.2 percentage points, even as unemployment rates lower the rate of borrowing over all ( 0.8 per 1 unit increase in the unemployment rate). This pattern is larger and stronger for households age 80-100. This result can provide evidence that older households are using mortgages as liquidity in response to unemployment shocks for either themselves or their family. These effects are relatively small in magnitude, however.

We next investigate the degree to which subsidies from the largest tax incentive for owning a home, the Mortgage Interest Deduction (MID) vary by age. Mortgage borrowers may deduct mortgage interest from federal (and typically state) income taxes 5

There is a vast literature studying the effects of MID on homeownership, prices, and household finance decisions, as well as a broader literature on the effects of tax policy

\footnotetext{
${ }^{5}$ The mortgage interest deduction is the second largest tax expenditure for individuals in the federal budget at $\$ 83$ billion in 2017 (Burman et al. 2008). The deduction is primarily an incentive to borrow using more mortgage debt. Taxpayers who take the standard deduction on their federal income taxes and do not claim the mortgage interest deduction do not directly benefit from the deduction. Lower-income owners receive a smaller deduction as a percentage of income than more affluent buyers even if they itemize their deductions.
} 
and homeownership (Gale et al., 2007) ${ }^{67}$ While previous research investigates the effects of the MID on homeownership, home prices, and household debt, prior studies have not focused on the heterogeneity of the effects of MID by age $]^{8}$ We use changes in marginal subsidy rates within states over time to estimate the effects of the MID on mortgage rates. Since there is only one state over our period that changes MID policy, our identification strategy relies on variation within state taxes over time. 9

Table 1 reports these results. There is no MID effect in borrowing overall for those over 50. However, a one percentage point increase in MID marginal subsidy rate decreases the gap between the mortgage rate of 65-79 and 50-64 year olds by one third of a percentage point. Given that the average combined federal and state marginal subsidy rate of mortgage interest has declined 8 percentage points between 1980 and 2015, this implies changes in the MID may explain around a quarter of the relative change in mortgage usage between 50-64 and 65-79 year olds over this time period. There are no statistically significant effects for the 80-100 year old group, suggesting the decrease in the gap between the mortgage rate of those 80-100 and 50-64 is not explained by these tax incentives.

We also report the results of the interaction with the Rent to Price (RTP) ratios (see Campbell et al. (2009) for a discussion of this measure). We choose the RTP measure over a traditional home price measure to capture the opportunity cost of owning versus renting. 10 We use RTP data available at the MSA-level, although this restricts the sample. For this population, a 1 unit (or one standard deviation) increase in the RTP ratio (times 100) increases the mortgage borrowing rate overall by 2.5 percentage points. For those 65-79 year old, the effect of RTP on mortgage rates is smaller, roughly 0.7 percentage points. This suggests that among this subgroup of urban households, older households in

\footnotetext{
${ }^{6}$ Variations exist in other countries, showing weak or mixed effects depending on the local context. For example, Jappelli and Pistaferri (2007) in Italy finds no effects of MID on homeownership or mortgage debt holding in Italy. Gruber et al. (2017) large changes in tax subsidies for owner-occupied housing were dominated by demographic and other factors. In the US, Ling and McGill (1998) and Dunsky and Follain (2000) find that when tax rates are cut, the relative tax price of mortgages increases, and mortgage debt falls. Hilber and Turner (2014) examines variation in the marginal subsidy to identify the effect of the MID on homeownership and house prices.

${ }^{7}$ The MID is built on the premise that positive externalities exist such that communities are better off with homeowners. However, there is little empirical evidence of this in practice. One exception is that Engelhardt et al. (2010) find that when randomizing homeownership via subsidized savings increases home maintenance expenditures. There are no effects of homeownership on investment in social capital, however.

${ }^{8}$ One paper by Poterba and Sinai (2008b) estimates simulated benefits of the MID by age, concluding households over age 65, on average, derive less value from the MID since their taxable income is relatively low.

${ }^{9}$ This is similar to Dunsky and Follain (2000); Ling and McGill (1998), except we focus on changes within state taxes instead of the 1986 federal tax reform.

${ }^{10}$ If we instead interact the HPI home price index with age, we see no differential effects.
} 
areas with relatively higher rents are more likely to have a mortgage-this could be due to limited options to move to rental housing but also because homeowners in these areas may have substantial home equity against which to borrow.

We combine all of these controls, as well as health status, wealth levels, bequest motives, state unemployment, MID and RTP to re-estimate the mortgage rate gap relative to 50-64 year olds in Table 11. The coefficients are similar to the prior estimates in all cases. The gap cannot be explained by these factors individually or collectively. The rising rate of using a mortgage appears to be statistically significant and narrowing over time.

\subsection{Consumption Shifts and Borrowing}

Table 2 provides one view of how households consume when they do and do not have mortgages. Specifically, Table 2 shows that while $65-79$ year olds spend roughly $\$ 80$ less than those 50-64 annually on food at home, there is no effect on in-home food consumption across those with and without mortgages. However, 65-79 year olds with mortgages spend roughly $\$ 185$ more on food away from home than those 65-79 year old without mortgages. This provides some suggestive evidence that 65-79 year olds with mortgages may be using some of their liquidity from increased mortgage borrowing for consumption. It is difficult to assess if this added consumption improves the welfare of households, but it at least suggests mortgage are not limiting consumption of one basic good, and to the extent food away from home is a more discretionary good, are consuming more of that type of good.

\section{Discussion}

Older households are using mortgages at higher rates, and borrowing more, than prior generations. This trend is not explained by increasing levels of income or education, or cohort shifts in marriage rates, urban location or race. Neither rising wealth, nor bequest motives substantially explain rising borrowing overall or within age groups. Rising rates of homeownership are an important component of this trend-more homeowners mechanically means more households who can borrow against home equity. Indeed, mortgage borrowing among older households accelerated with the housing boom in the mid-2000s. Changes to local housing markets tax laws, and housing consumption preferences also appear to contribute to differential changes in mortgage usage by age.

Examining sub-groups of households helps illuminate these patterns. Households with below-median assets and those without pensions account for most of the increase in bor-

rowing. Yet there are no signs of rising defaults or financial hardship for these older households with mortgage debt. 
Relatively older homeowners without other assets, especially non-retirement assets, may simply be borrowing to fund consumption in the present-there are some patterns of borrowing in response to local unemployment rates that are consistent with this concept. This could be direct consumption or to help family members.

Older homeowners are holding on to their homes, and their mortgages, longer and potentially smoothing consumption or preserving liquid savings. Low interest rates may have enticed many homeowners in their 50s and 60s into refinancing in the 2000s. Those loans had low rates, and given the decline in home equity and also other asset values in the recession, paying off these loans was less feasible. There is also some evidence that borrowing tends to be more common in areas where the relative costs of renting are higher-limiting other options. Whether these patterns are sustained as more current aging cohorts retire from work, housing prices appreciate, and interest rates increase remains ambiguous.

The increase in the use of mortgages by older households is a trend worthy of more study. This is also an important issue for financial planners, and policy makers, to monitor over the next few years as more cohorts of older households retire, and existing retirees either take on more debt or pay off their loans. Likewise, estate sales of property and probate courts may find more homes encumbered with a mortgage. Surviving widows and widowers may struggle to pay mortgage payments after the death of a spouse and may face a reduction of pension or Social Security payments. This may be a form of default risk not currently priced into mortgage underwriting for older loan applicants. If more mortgage borrowing among the elderly results in more foreclosures, smaller inheritances, or even estates with negative values, this could have negative effects on extended families and communities.

\section{References}

Amromin, Gene, Jennifer Huang, and Clemens Sialm, "The tradeoff between mortgage prepayments and tax-deferred retirement savings," Journal of Public Economics, 2007, 91 (10), 2014-2040.

Bhutta, Neil and Benjamin J Keys, "Interest rates and equity extraction during the housing boom," The American Economic Review, 2016, 106 (7), 1742-1774.

Bricker, Jesse, Brian Bucks, Arthur Kennickell, Traci Mach, and Kevin Moore, "The financial crisis from the family's perspective: Evidence from the 2007-2009 SCF panel," Journal of Consumer Affairs, 2012, 46 (3), 537-555. 
Brown, Meta, Donghoon Lee, Joelle Scally, Katherine Strair, and H. Wilbert Van der Klaauw, "The Graying of American Debt," Federal Reserve Bank of New York, Research and Statistics Group, Microeconomic Studies, February, 2016, February 24, 2016-9.

Burman, Leonard E, Christopher Geissler, and Eric J Toder, "How big are total individual income tax expenditures, and who benefits from them?," The American Economic Review, 2008, 98 (2), 79-83.

Campbell, Sean D, Morris A Davis, Joshua Gallin, and Robert F Martin, "What moves housing markets: A variance decomposition of the rent-price ratio," Journal of Urban Economics, 2009, 66 (2), 90-102.

Consumer Financial Protection Bureau, "Snapshot of older consuemrs and mortgage debt," CFPB Office for Older Americans, 2014, May, 1-18.

Davidoff, Thomas, "Home equity commitment and long-term care insurance demand," Journal of Public Economics, 2010, 94, 44-49.

Dietz, Robert D and Donald R Haurin, "The social and private micro-level consequences of homeownership," Journal of urban Economics, 2003, 54 (3), 401-450.

Dunsky, Robert and James Follain, "Tax-Induced Portfolio Reshuffling: The Case of the Mortgage Interest Deduction," Real Estate Economics, 2000, 28, 638-718.

Engelhardt, Gary, Michael Eriksen, William Gale, and Gregory Mills, "What Are the Social Benefits of Homeownership? Experimental Evidence for Low-Income Households," Journal of Urban Economics, 2010, 67, 249-258.

Engelhardt, Gary V., "Social security and elderly homeownership," Journal of Urban Economics, 2008, 63 (1), 280 - 305.

- and Nadia Greenhalgh-Stanley, "Home health care and the housing and living arrangements of the elderly," Journal of Urban Economics, 2010, 67 (2), 226 - 238.

Gale, William, Jonathan Gruber, and Seth Stepehns-Davidowtiz, "Encouraging Homeownership Through the Tax Code," Tax Notes, 2007, 115, 1171-1189.

Golant, Stephen M, "Commentary: Irrational exuberance for the aging in place of vulnerable low-income older homeowners," Journal of Aging \& Social Policy, 2008, 20 (4), 379-397. 
_ , "Low-income Elderly Homeowners in Very Old Dwellings: the Need for Public Policy Debate," Journal of Aging \& Social Policy, 2008, 20 (1), 1-28.

Goodman, Laurie $\mathbf{S}$ and Christopher Mayer, "Homeownership and the American Dream," Journal of Economic Perspectives, 2018, 32 (1), 31-58.

Gruber, Jonathan, Amalie Jensen, and Henrik Kleven, "Do People Respond to the Mortage Interest Deduction? Quasi-Experimental Evidence from Denmark," NBER Working Paper, 2017, 23600.

Gyourko, Joseph and Joseph Tracy, "Using Home Maintenance and Repairs to Smooth Variable Earnings," The Review of Economics and Statistics, 2006, 88 (4), 736-747.

Hanson, Andrew, "Size of home, homeownership, and the mortgage interest deduction," Journal of Housing Economics, 2012, 21 (3), 195-210.

Hilber, Christian and Tracy Turner, "The Mortgage Interest Deduction and Its Impact on Homeownership Decisions," Review of Economics and Statistics, 2014, 96 (4), 618637.

Jappelli, Tullio and Luigi Pistaferri, "Do people respond to tax incentives? An analysis of the Italian reform of the deductibility of home mortgage interests," European Economic Review, 2007, 51 (2), 26-35.

Ling, David and Gary McGill, "Evidence on the Demand for Mortgage Debt by OwnerOccupants," Journal of Urban Economics, 1998, 44, 391-414.

Lusardi, Annamaria and Olivia Mitchell, "Baby boomer retirement security: The roles of planning, financial literacy, and housing wealth.," Journal of Monetary Economics, 2007, 54 (1), 205-224.

_, , , and Noemi Oggero, "Debt and Financial Vulnerability on the Verge of Retirement," NBER Working Paper, 2017, August (23664).

_, Olivia S Mitchell, and Noemi Oggero, "Debt and financial vulnerability on the verge of retirement," Technical Report, National Bureau of Economic Research 2017.

Mayer, Christopher J, "Housing, Mortgages, and Retirement," Evidence and Innovation in Housing Law and Policy, 2017, p. 203.

Moulton, Stephanie, Cäzilia Loibl, and Donald Haurin, "Reverse mortgage motivations and outcomes: Insights from survey data," Cityscape, 2017, 19 (1), 73. 
Nason, Deborah, "Pros and cons of paying off mortgage before retirement," 2017.

Painter, Gary and KwanOk Lee, "Housing tenure transitions of older households: Life cycle, demographic, and familial factors," Regional Science and Urban Economics, 2009, 39 (6), 749-760.

Pham, Sherisse, "Retirements swallowed by debt," New York Times, 2011.

Poterba, James and Todd Sinai, "Tax expenditures for owner-occupied Housing: Deductions for Property Taxes and mortgage interest and the exclusion of imputed rental income," American Economic Review, 2008, 98 (2), 84-89.

_ and _ , "Tax expenditures for owner-occupied Housing: Deductions for Property Taxes and mortgage interest and the exclusion of imputed rental income," The American Economic Review, 2008, 98 (2), 84-89.

Poterba, James M, "Retirement security in an aging population," The American Economic Review, 2014, 104 (5), 1-30.

Poterba, James, Steven Venti, and David Wise, "The composition and drawdown of wealth in retirement," The Journal of Economic Perspectives, 2011, 25 (4), 95-117.

Sabia, Joseph J, "There's no place like home: a hazard model analysis of aging in place among older homeowners in the PSID," Research on Aging, 2008, 30 (1), 3-35.

Shan, Hui, "Property taxes and elderly mobility," Journal of Urban Economics, 2010, 67 (2), $194-205$.

_ , "Reversing the trend: The recent expansion of the reverse mortgage market," Real Estate Economics, 2011, 39 (4), 743-768.

Sinai, Todd and Nicholas S Souleles, "Owner-occupied housing as a hedge against rent risk," The Quarterly Journal of Economics, 2005, 120 (2), 763-789.

Venti, Steven F. and David A. Wise, "Aging and the income value of housing wealth," Journal of Public Economics, 1991, 44 (3), 371 - 397. Special Issue on International Studies of Housing Demand: The Effects of Government Policies.

Vornovytskyy, Marina, Alfred Gottschalck, and Adam Smith, "Household Debt in the US: 2000 to 2011,” Technical Report, US Census Bureau, Washington, DC 2011. 
Figure 1: Mortgage Holding Rates by Age Profiles over Time

Panel A: American Housing Survey

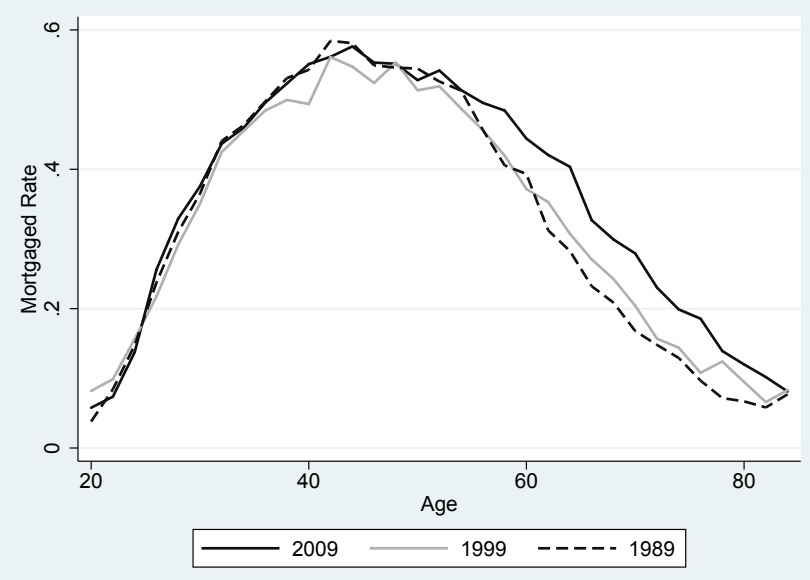

Panel B: Census

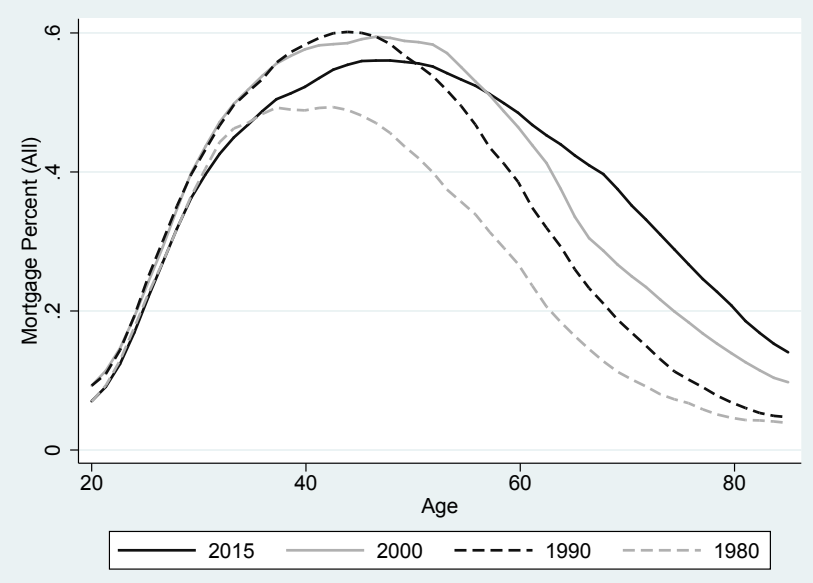

Source: American Housing Survey. Census PUMS Data 1980-2000, 2015 American Community Survey Data.

Figure 2: Homeownership Rate Age Profiles (Census)

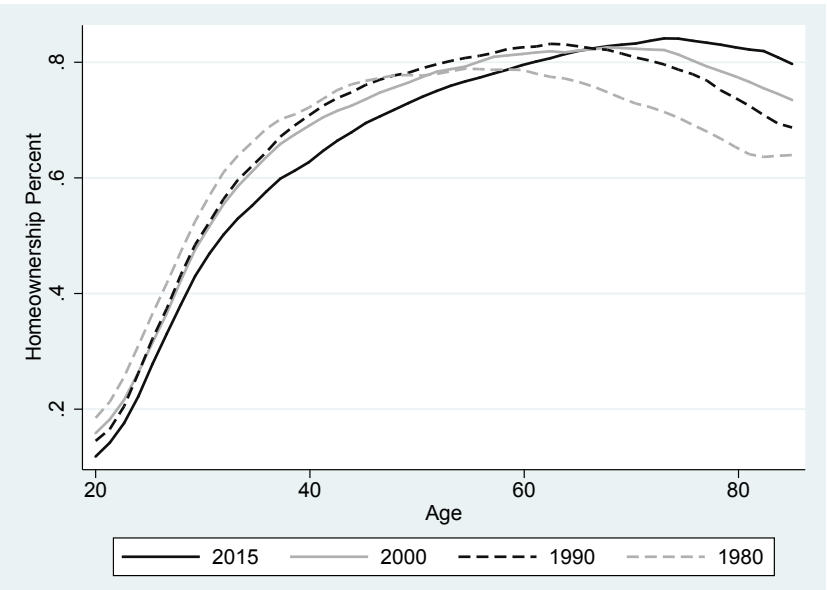

Source: Census PUMS Data 1980-2000, 2015 American Community Survey Data. 
Figure 3: Wealth \& Retirement Age Profiles

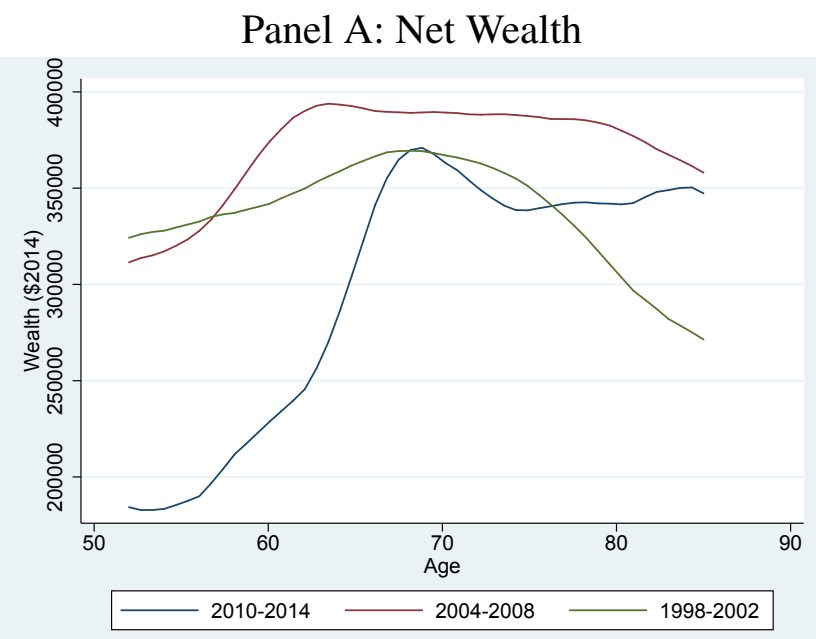

Panel B: Wealth Greater than $\$ 50,000$

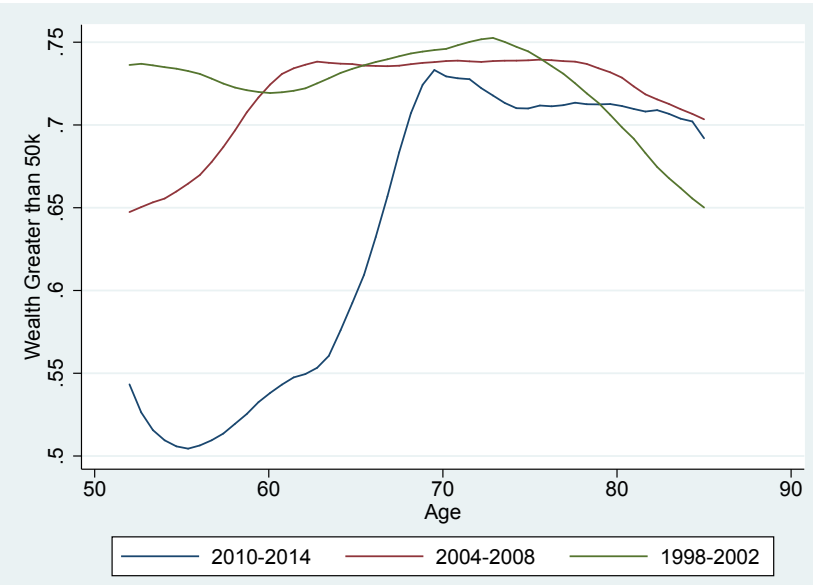

\section{Panel C: Retirement}

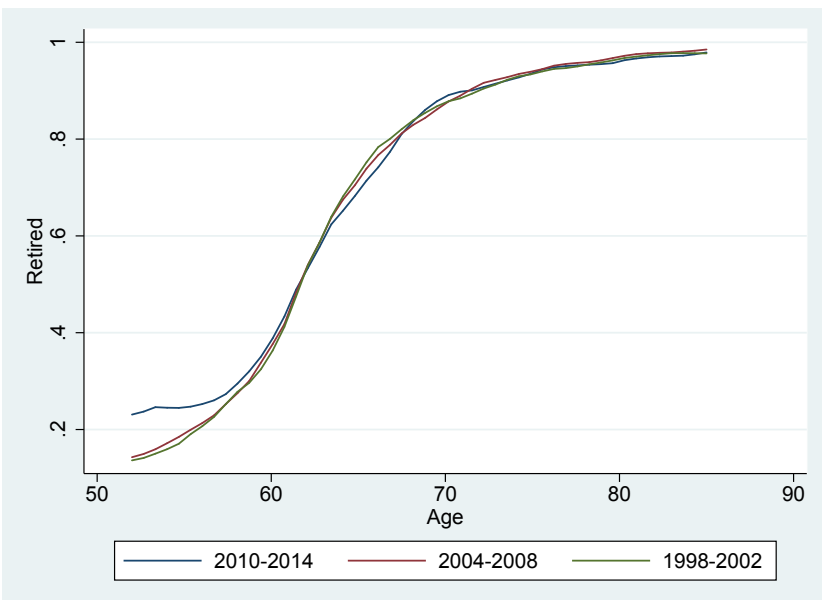

Source: Health and Retirement Study Data. 
Figure 4: The Prevalence of Mortgage by Age Cohort over Time

Panel A: Health and Retirement Study Panel B: Survey of Consumer Finances
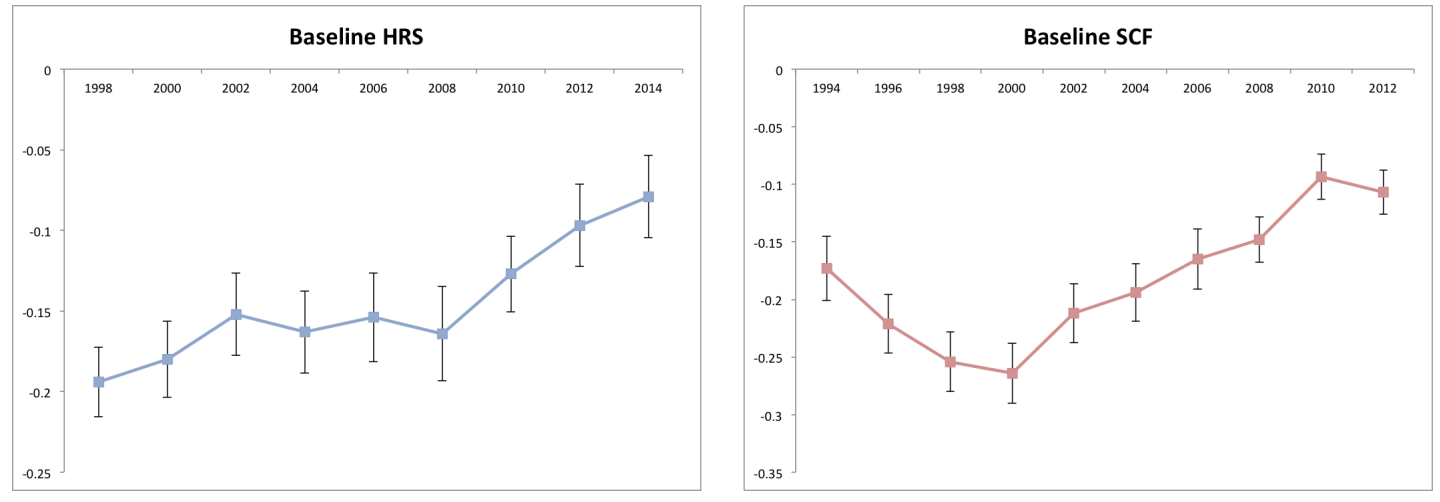

Panel C: Census

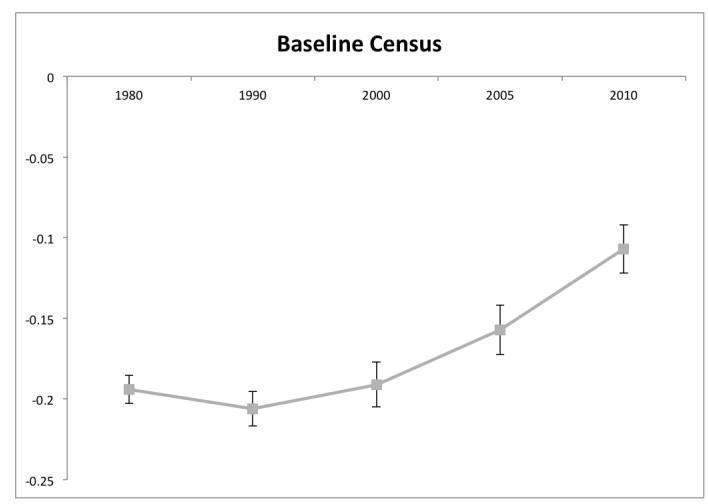

Source: HRS, SCF, and Census Data, respectively. Estimates $\alpha_{1}$ coefficients from Equation 1 in each dataset with standard error bars reported for each coefficient. Coefficient estimates are in Appendix Table 3 
Figure 5: Heterogeneity in Age Profiles

A. Num. Children

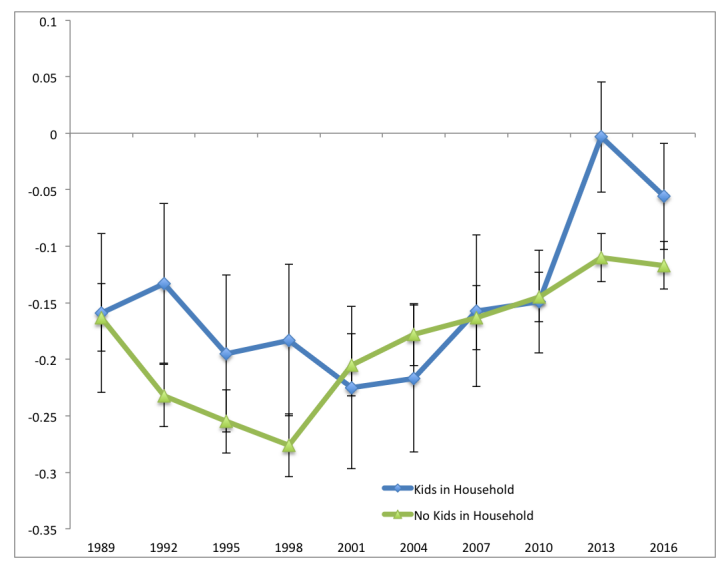

C. Education Level

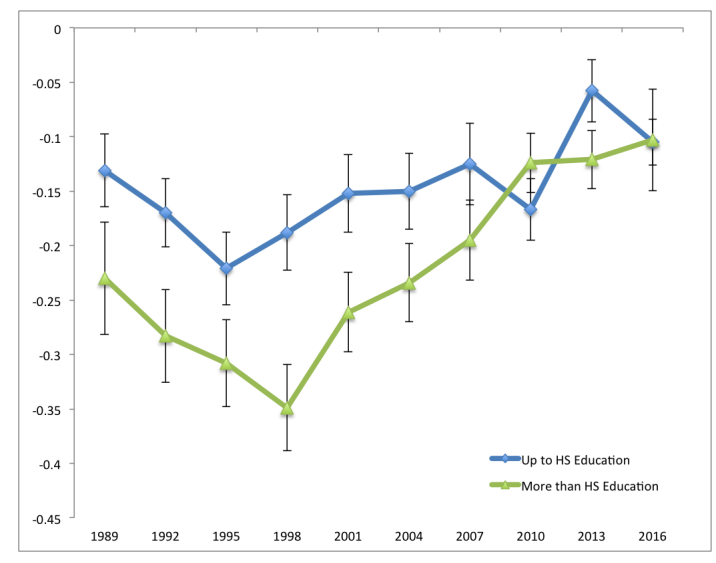

E. State Unemployment

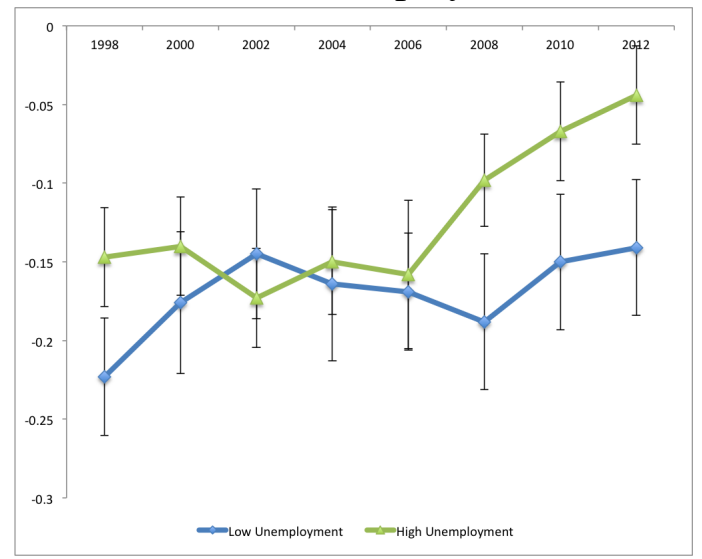

B. Pension

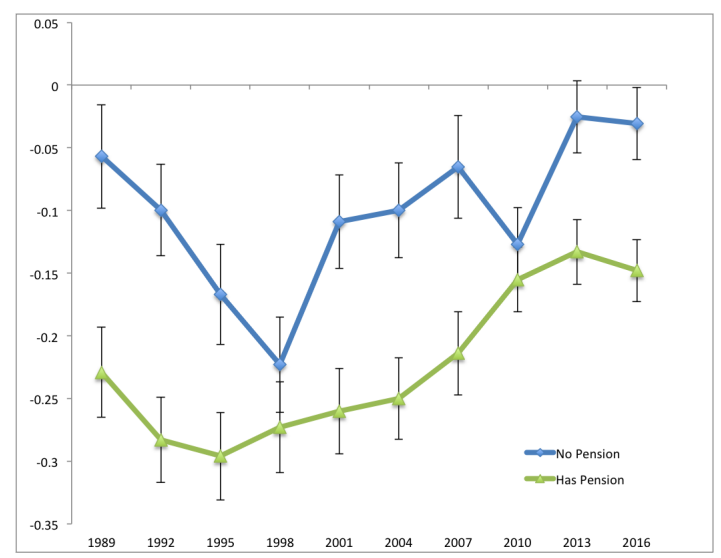

D. Net Worth

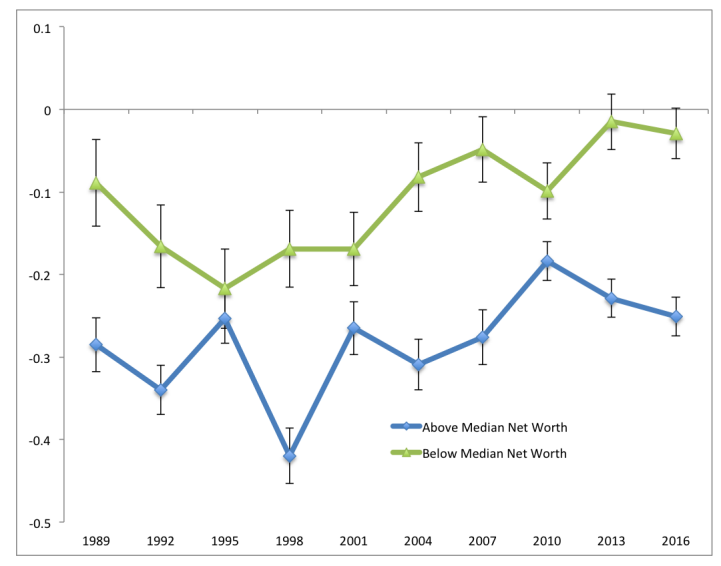

F. Bequest Motive

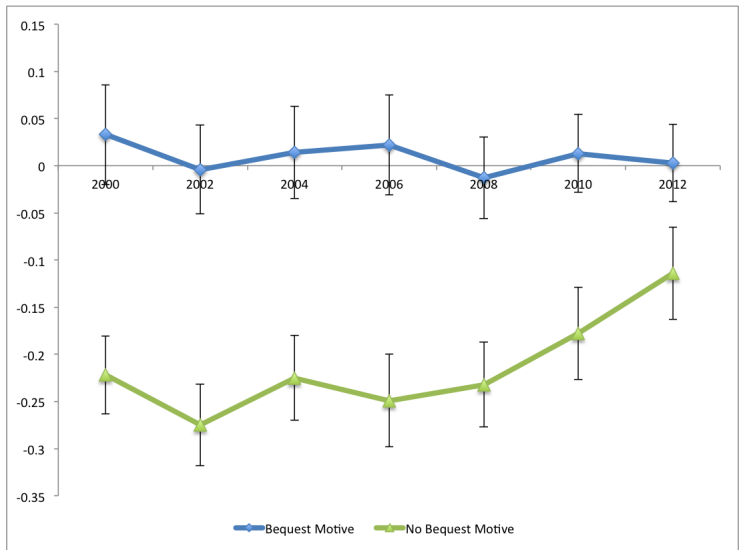

Source: 1989-2016 SCF Data in top two rows and HRS data in the bottom row. Estimates $\alpha_{1}$ coefficients from Equation 1 for each group of interest with standzkd error bars reported for each coefficient. Coefficient estimates are in Appendix Tables 4,5 and 6 for rows 1, 2, and 3, respectively. 
Figure 6: Homeownership Rates Increasing for Older Households Relative to 50-64 Year Olds

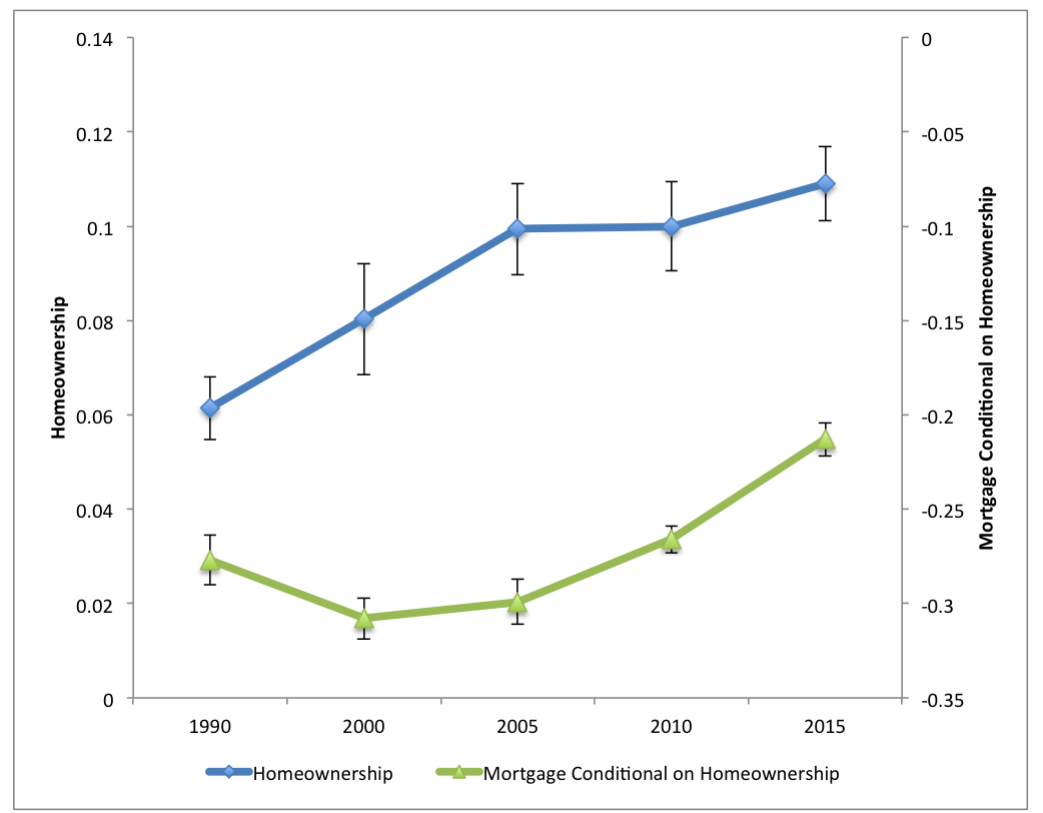

Source: Census Data. Estimates $\alpha_{1}$ coefficients from Equation 1 for each group of interest with standard error bars reported for each coefficient. Coefficient estimates are in Appendix Table 7 The bottom panel of Appendix Table 7 confirms the trend in the HRS data. 
Figure 7: Home Values and Second Homes for Older Households Relative to 50-64 Year Olds

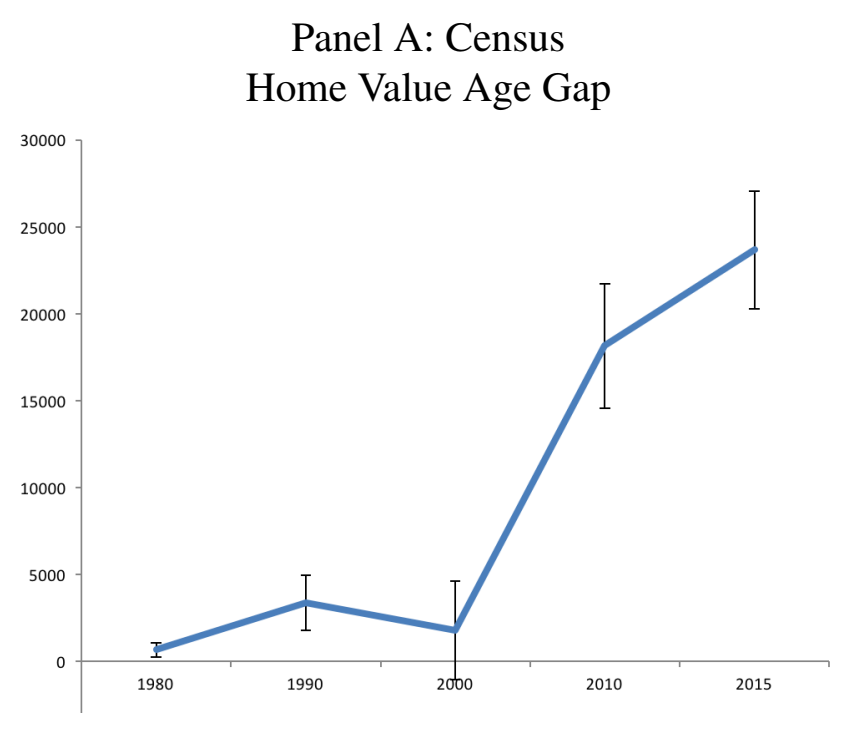

Panel B: Health and Retirement Survey
Rate of Second Home Mortgages Age Gap

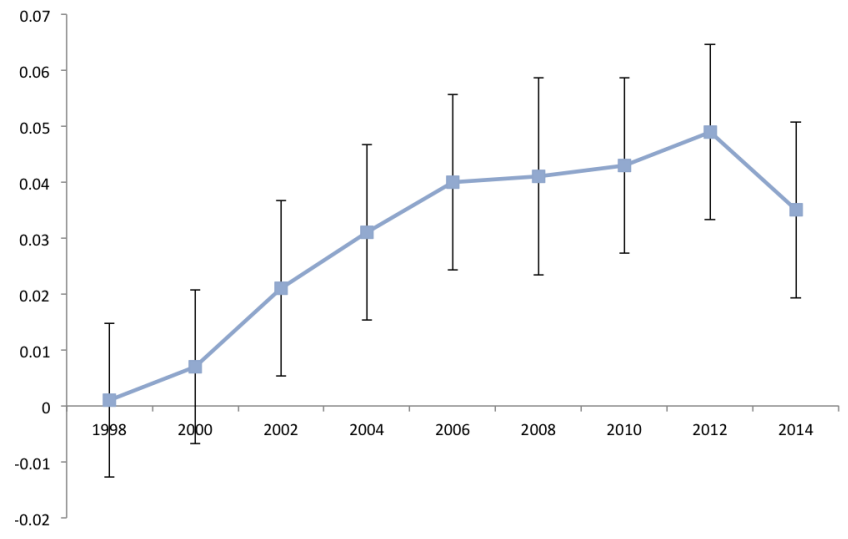

Source: Census PUMS Data 1980-2000, 2015 American Community Survey Data (Top Panel), HRS Data (Bottom Panel). Estimates $\alpha_{1}$ coefficients from Equation 11 for each group of interest with standard error bars reported for each coefficient. Full coefficient estimates are in Appendix Table 8 
Figure 8: Refinance and Equity Extraction Becoming Relatively more Common Among 65-79 Year Olds Compared to 50-64 Year Olds, Decrease in Home Equity for Older Households

Panel A: Survey of Consumer Finances Cash out Refinance

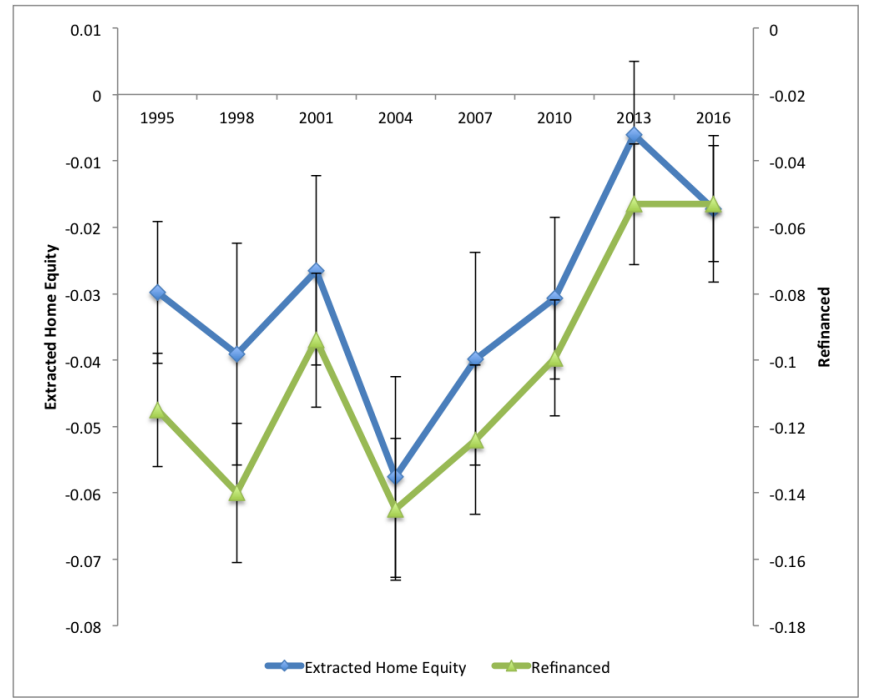

Panel B: Survey of Consumer Finances Home Equity

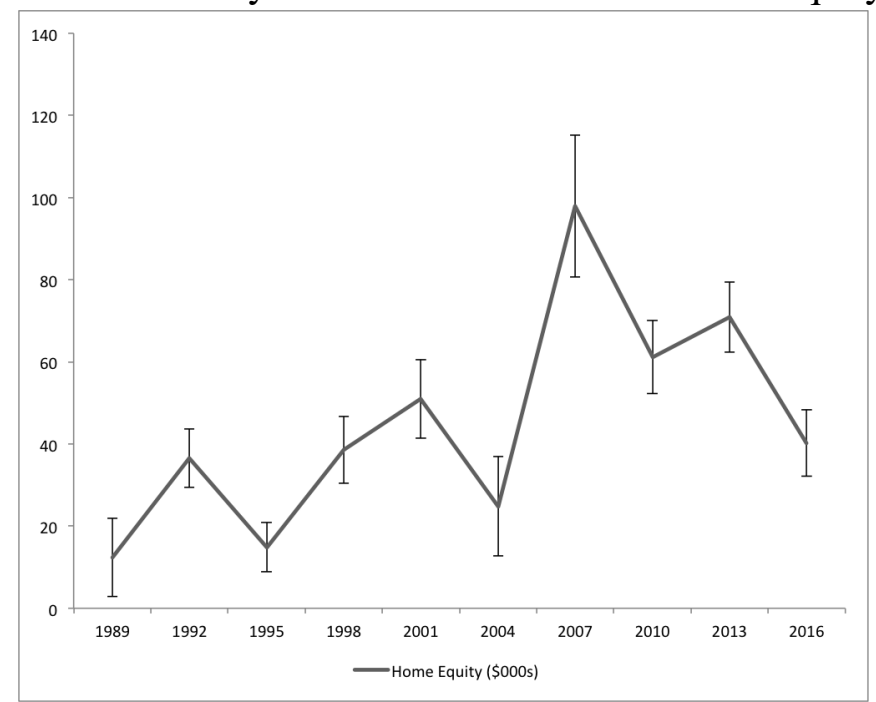

Source: SCF Data. Plots include estimates of $\alpha_{1}$ coefficients from Equation 1$]$ with standard error bars. Bottom figure is in continuous dollars. Coefficient estimates are in Appendix Table 9. 
Figure 9: Household Liquid Savings and Late Fees

\section{Panel A: Survey of Consumer Finances: Liquid Savings}

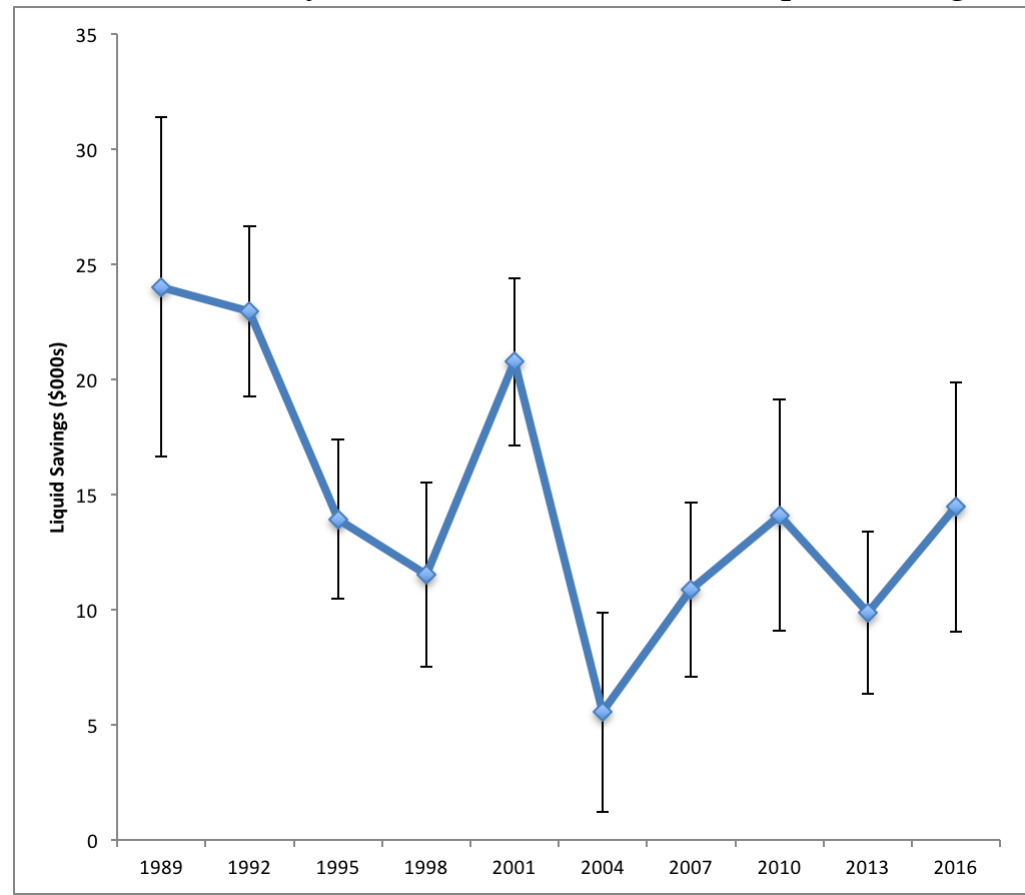

Panel B: Survey of Consumer Finances: Late Payments

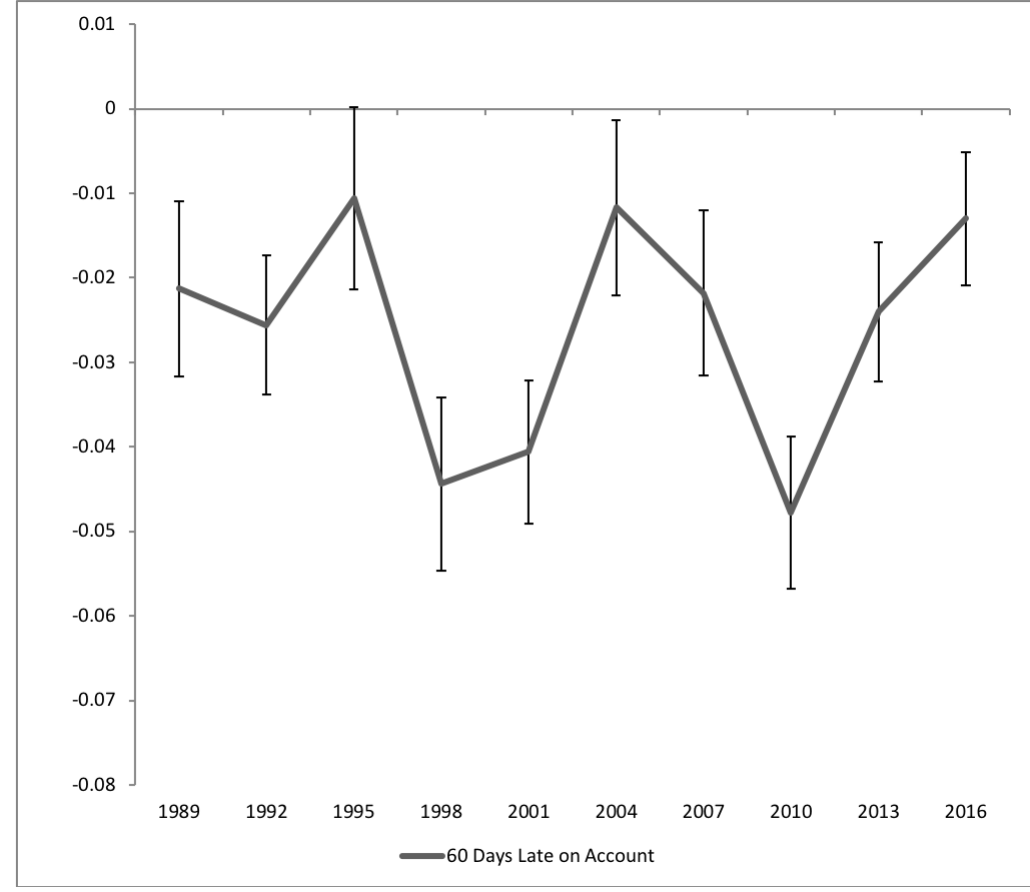

Source: Survey of Consumer Finances. Estimates $\alpha_{1} 2$ cheefficients from Equation 1 for each group of interest with standard error bars reported for each coefficient. Coefficient estimates are in Appendix Table 10 
Table 1: Time Varying Factors Affecting Elderly Mortgages Differentially (HRS)

\begin{tabular}{|c|c|c|c|}
\hline \multicolumn{4}{|c|}{ Dependent Variable=Mortgage } \\
\hline & (1) & (2) & (3) \\
\hline $65-79$ & $\begin{array}{c}-0.034 * * * \\
(0.009)\end{array}$ & $\begin{array}{c}-0.031 * * * \\
(0.006)\end{array}$ & $\begin{array}{l}0.075^{* *} \\
(0.031)\end{array}$ \\
\hline $80-100$ & $\begin{array}{c}-0.040 * * * \\
(0.015)\end{array}$ & $\begin{array}{l}-0.000 \\
(0.011)\end{array}$ & $\begin{array}{c}0.182 * * * \\
(0.050)\end{array}$ \\
\hline State Unemployment Rate & $\begin{array}{c}-0.008 * * * \\
(0.001)\end{array}$ & & \\
\hline $65-79 \times$ Unemployment & $\begin{array}{l}0.002 * \\
(0.001)\end{array}$ & & \\
\hline 80-100 × Unemployment & $\begin{array}{c}0.006 * * * \\
(0.002)\end{array}$ & & \\
\hline State MID & & $\begin{array}{l}-0.004 \\
(0.004)\end{array}$ & \\
\hline $65-79 \times \mathrm{MID}$ & & $\begin{array}{c}-0.003 * * \\
(0.001)\end{array}$ & \\
\hline $80-100 \times$ MID & & $\begin{array}{l}-0.001 \\
(0.003)\end{array}$ & \\
\hline MSA RTP & & & $\begin{array}{c}0.0252 * * \\
(0.0166)\end{array}$ \\
\hline $65-79 \times \mathrm{RTP}$ & & & $\begin{array}{c}-0.0180 * * * \\
(0.00664)\end{array}$ \\
\hline $80-100 \times \mathrm{RTP}$ & & & $\begin{array}{c}-0.0408 * * * \\
(0.0112)\end{array}$ \\
\hline $\mathrm{N}$ & 58,949 & 58,950 & 14,879 \\
\hline
\end{tabular}

Notes: Linear probability models with robust standard errors clustered at the state-level in parentheses. * $p<0.10, * * p<0.05, * * * p<0.01$ Each observation is a respondent-year. All models include state and year fixed effects and control for number of children, logged income, urban area, greater than high school education, race, and marital status. Unemployment rate is the state unemployment rate that year. MID is equal to the mortgage interest deduction subsidy in the state and year of the interview. RTP is annual average rents divided by average price levels in a given MSA and year. Data from the HRS. 
Table 2: Mortgages and Food Expenditures at Home and Away from Home (SCF)

\begin{tabular}{|c|c|c|}
\hline \multicolumn{3}{|c|}{ Dependent Variable=Annual Food Expenditures } \\
\hline & Home & Away \\
\hline $65-79$ & $-80.83^{* * *}$ & $-152.5^{* * * *}$ \\
\hline $80-100$ & $\begin{array}{c}(18.77) \\
-386.0 * * * \\
(28.32)\end{array}$ & $\begin{array}{c}(14.40) \\
-225.6^{* * * *} \\
(22.80)\end{array}$ \\
\hline $65-79 \times$ Mortgage & $\begin{array}{l}-51.49^{*} \\
(30.53)\end{array}$ & $\begin{array}{c}184.5 * * * \\
(26.32)\end{array}$ \\
\hline $80-100 \times$ Mortgage & $\begin{array}{c}27.57 \\
(83.19)\end{array}$ & $\begin{array}{l}-126.3^{*} \\
(66.55)\end{array}$ \\
\hline $\mathrm{N}$ & 124,211 & 124,211 \\
\hline
\end{tabular}

Notes: OLS regressions with robust standard errors in parentheses. $p<0.10, * * p<0.05, * * * p<0.01$ Each observation is a respondent-year. All models include controls for minority race, marital status, and high school education indicators, as well as income level, and number of children. Household weights. SCF data. 


\section{Appendix}




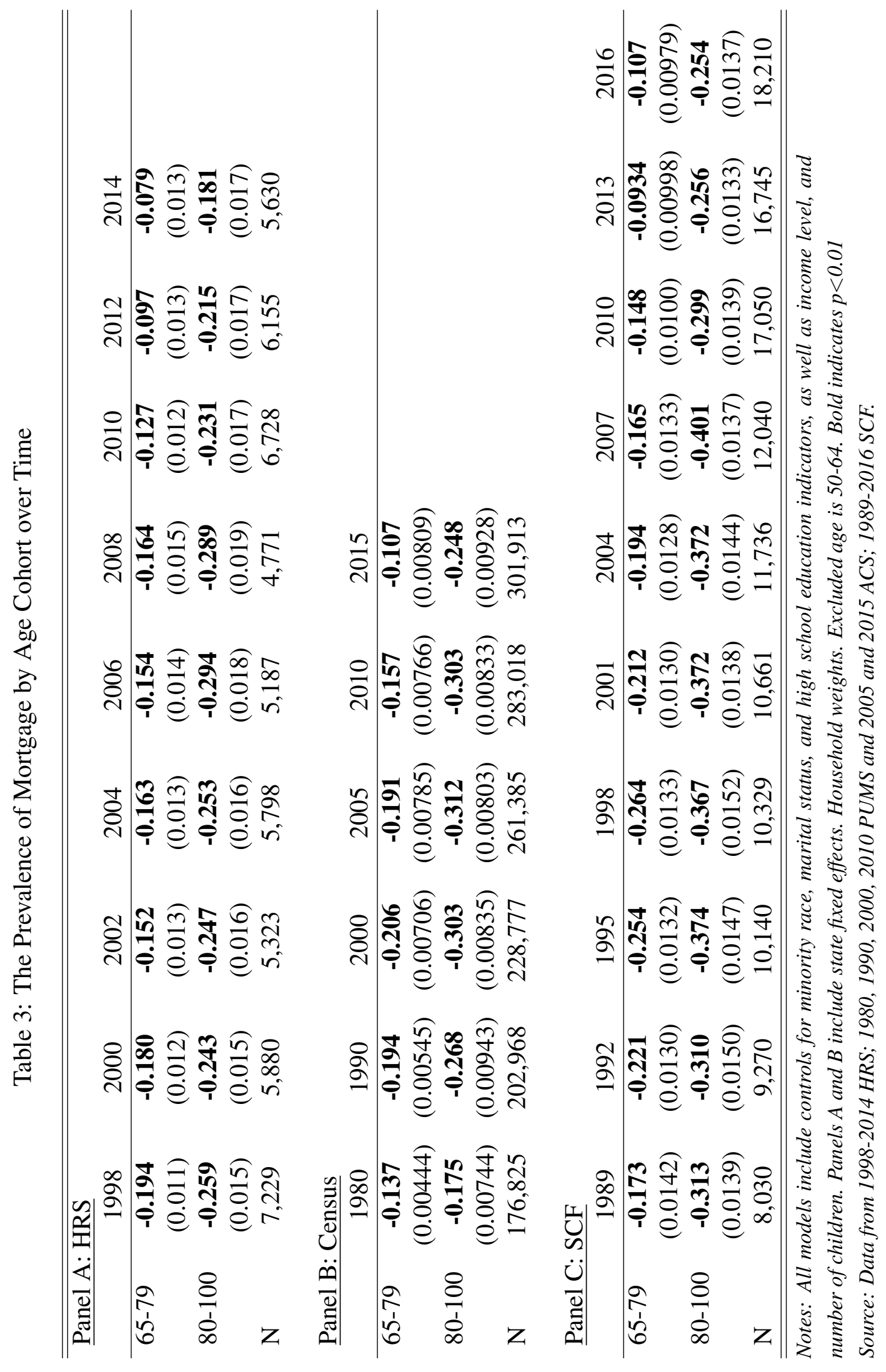




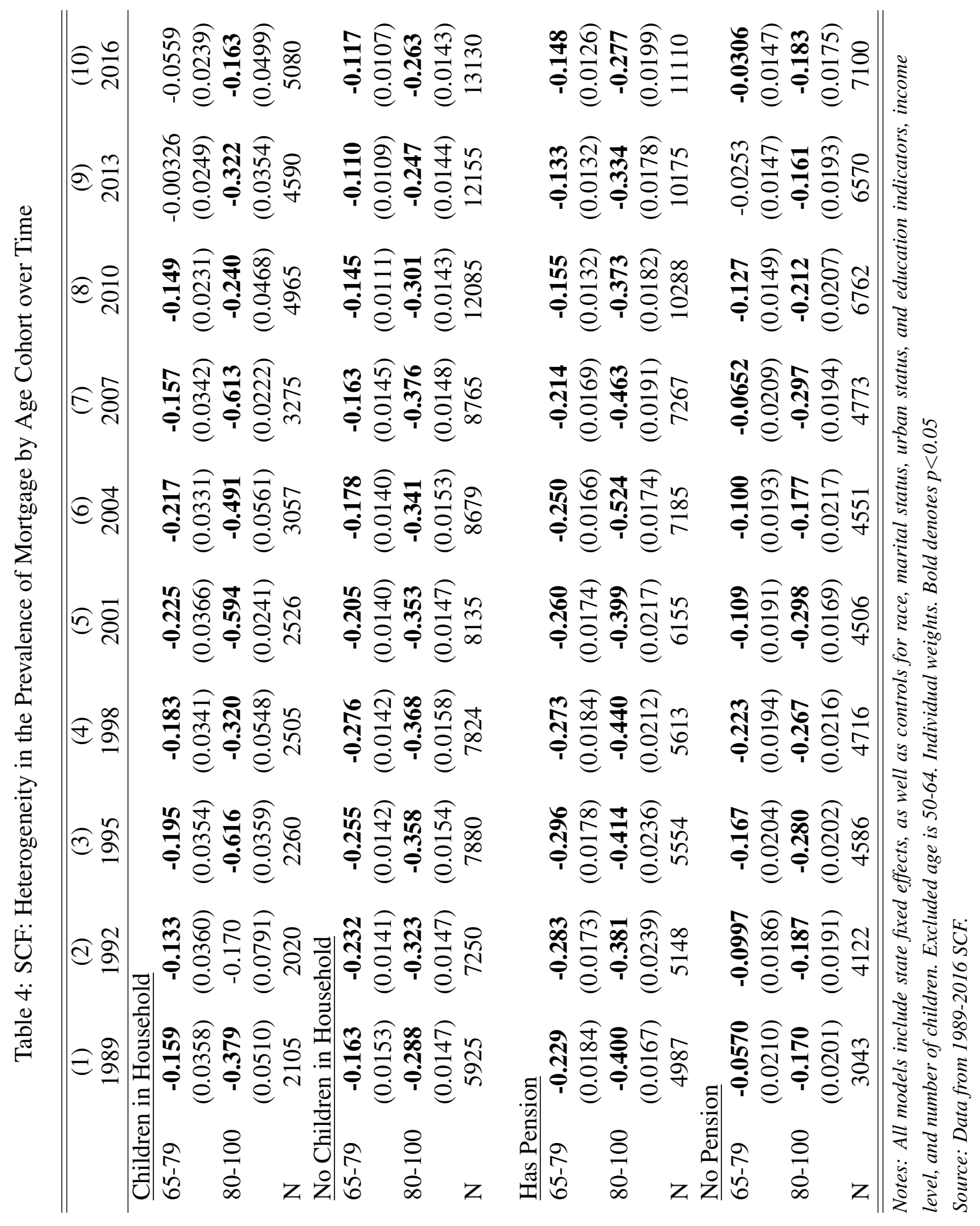




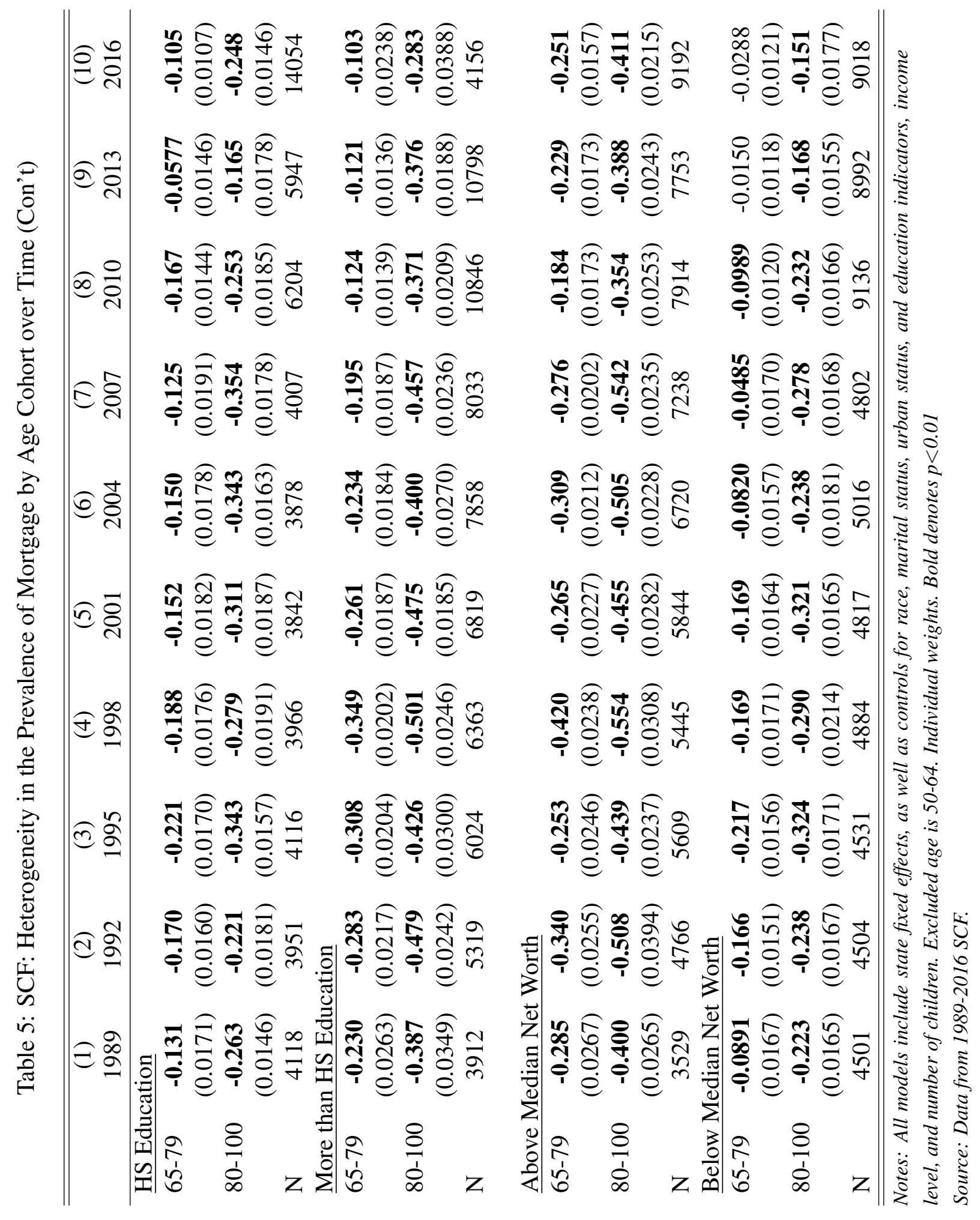




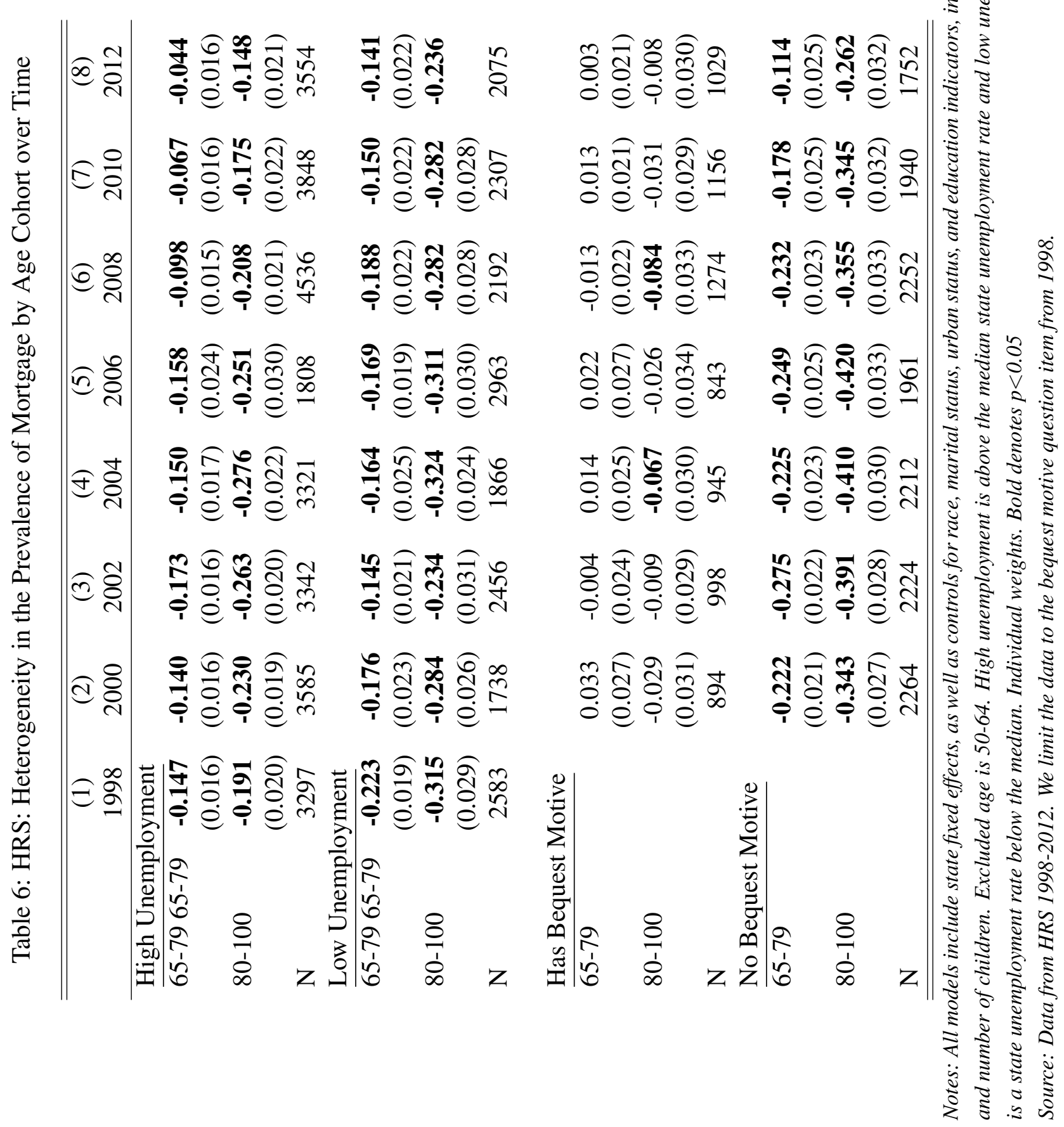




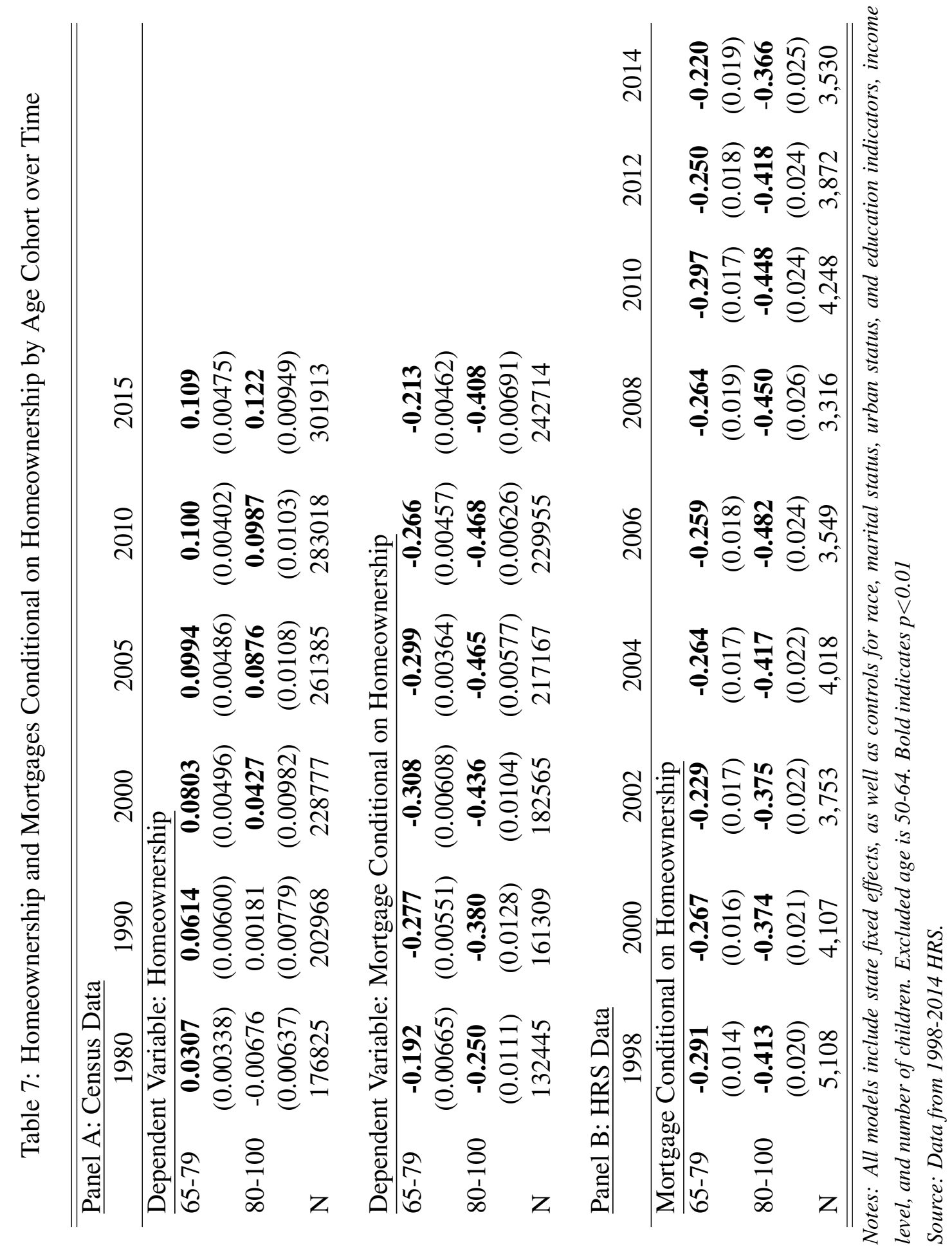




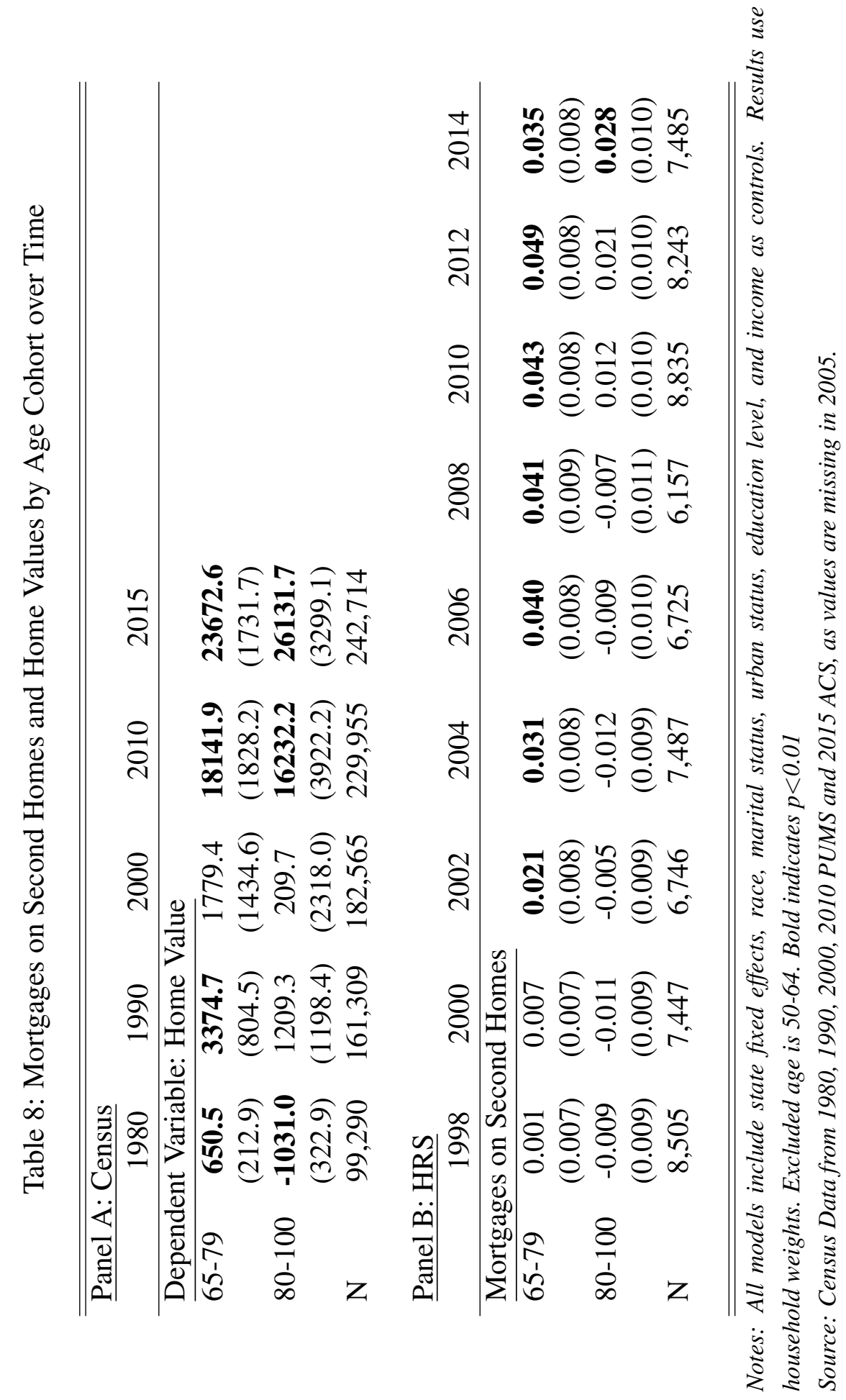




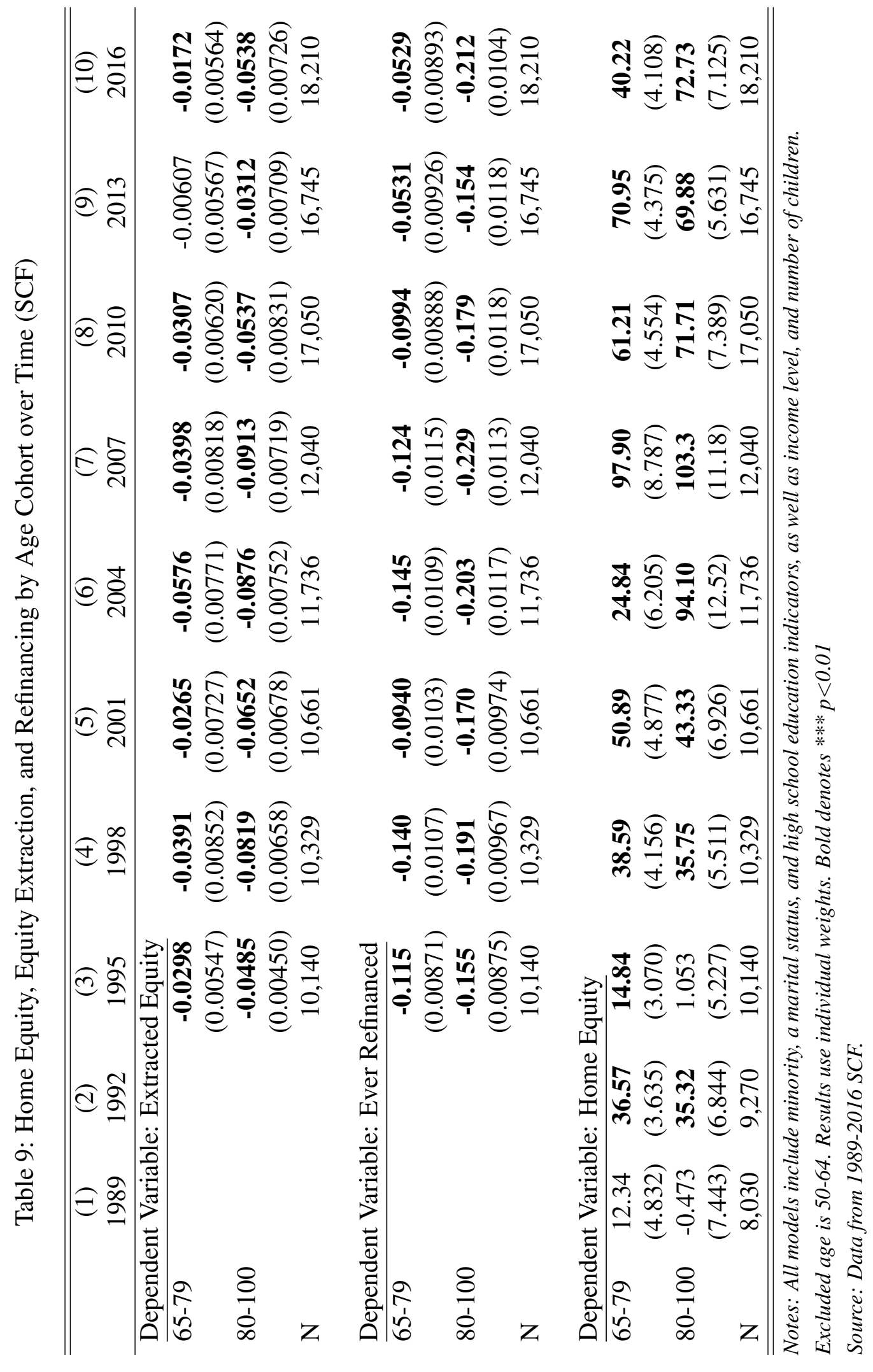




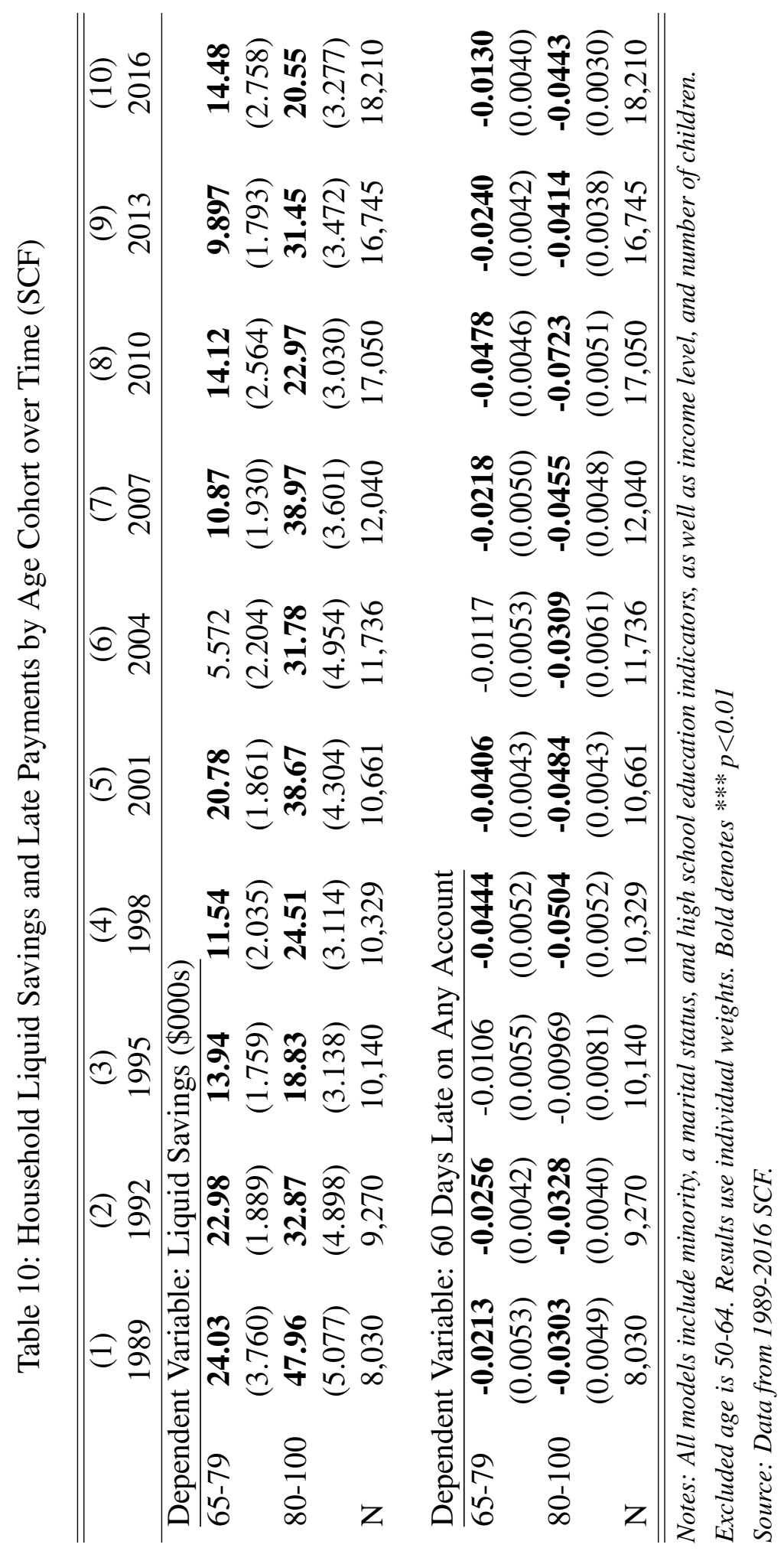




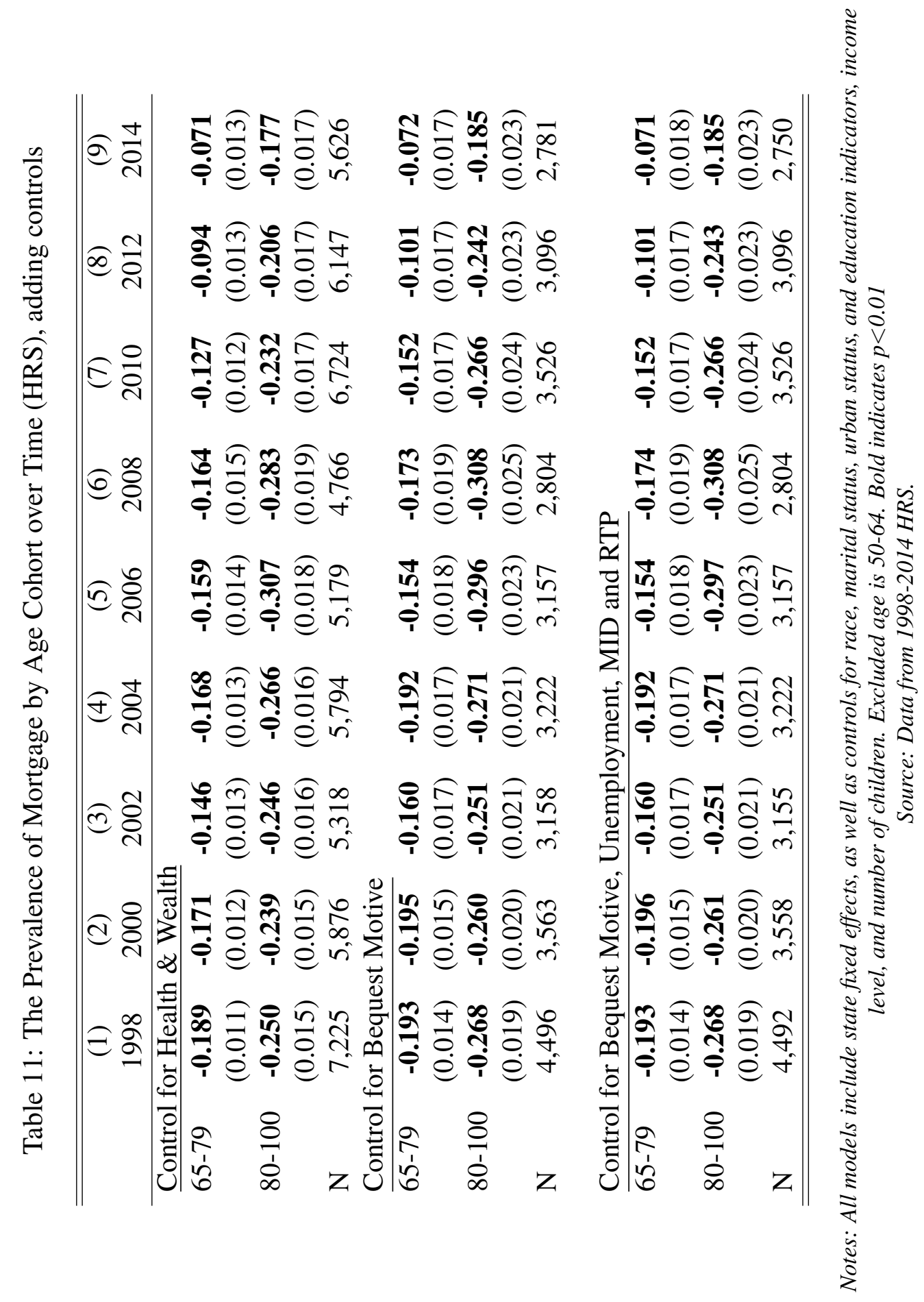




\section{RECENT WORKING PAPERS FROM THE CENTER FOR RETIREMENT RESEARCH AT BOSTON COLLEGE}

How Might Earnings Patterns and Interactions Among Certain Provisions in OASDI Solvency Packages Affect Financing and Distributional Goals?

Melissa M. Favreault, March 2018

Distributional Effects of Alternative Strategies for Financing Long-Term Services and Supports and Assisting Family Caregivers

Melissa M. Favreault and Richard W. Johnson, March 2018

How to Pay for Social Security's Missing Trust Fund?

Alicia H. Munnell, Wenliang Hou, and Geoffrey T. Sanzenbacher, December 2017

Retirement Prospects for the Millennials: What is the Early Prognosis?

Richard W. Johnson, Karen E. Smith, Damir Cosic, and Claire Xiaozhi Wang, November 2017

Mom and Dad We're Broke, Can You Help? A Comparative Study of Financial Transfers Within Families Before and After the Great Recession

Mary K. Hamman, Daniela Hochfellner, and Pia Homrighausen, November 2017

Homeownership, Social Insurance, and Old-Age Security in the United States and Europe Stipica Mudrazija and Barbara A. Butrica, October 2017

How Much Does Motherhood Cost Women in Social Security Benefits?

Matthew S. Rutledge, Alice Zulkarnain, and Sara Ellen King, October 2017

How Much Does Out-of-Pocket Medical Spending Eat Away at Retirement Income?

Melissa McInerney, Matthew S. Rutledge and Sara Ellen King, October 2017

Can Knowledge Empower Women to Save More for Retirement?

Drew M. Anderson and J. Michael Collins, September 2017

Dementia, Help with Financial Management, and Well-Being

Anek Belbase and Geoffrey T. Sanzenbacher, September 2017

The Behavioral and Consumption Effects of Social Security Changes

Wenliang Hou and Geoffrey T. Sanzenbacher, September 2017

Family Transfers With Retirement-Aged Adults in the United States: Kin Availability, Wealth Differentials, Geographic Proximity, Gender, and Racial Disparities Ashton M. Verdery, Jonathan Daw, Colin Campbell, and Rachel Margolis, August 2017

All working papers are available on the Center for Retirement Research website (http://crr.bc.edu) and can be requested by e-mail (crr@bc.edu) or phone (617-552-1762). 